MLM-3807

UC-702

\title{
Mound Plant Environmental \\ Monitoring Plan
}

L. R. Bauer, M. S. Tullis,

R. P. Paulick, and L. L. Roush

Issued: July 18, 1994

\section{MOUND}

operated by

EGIG MOUND APPLIED TECHNOLOGIES

P.O. Box 3000. Miamisburg. Ohio 45343-3000

for the

U. S. DEPARTMENT OF ENERGY

MASTER

Contract No. DE-AC04-88DP43495 


\title{
MOUND \\ ENVIRONMENTAL MONITORING PLAN
}

\author{
AL/EPD Reviewers: Shiv Goel \\ Karen S. McAda \\ Frank H. Sprague
}

Approved by:

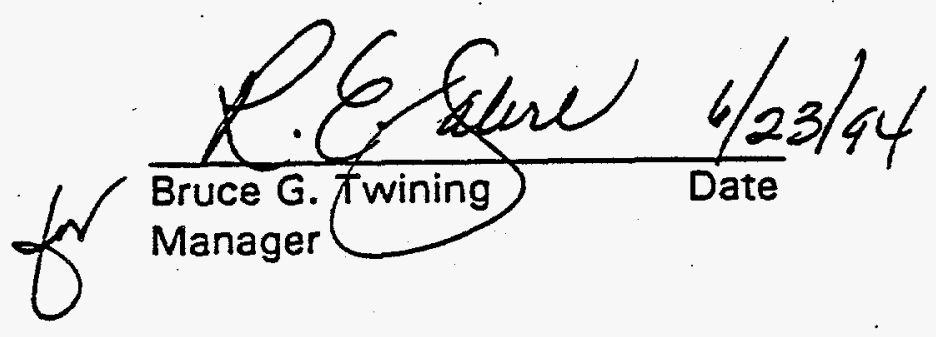

DISCLAIMER

This report was prepared as an account of work sponsored by an agency of the United States Government. Neither the United States Government nor any agency thereof, nor any of their employees, makes any warranty, express or implied, or assumes any legal liability or responsibility for the accuracy, completeness, or usefulness of any information, apparatus, product, or process disclosed, or represents that its use would not infringe privately owned rights. Reference herein to any specific commercial product, process, or service by trade name, trademark, manufacturer, or otherwise does not necessarily constitute or imply its endorsement, recommendation, or favoring by the United States Government or any agency thereof. The views and opinions of authors expressed herein do not necessarily state or reflect those of the United States Government or any agency thereof. 


\section{DISCLAIMER}

Portions of this document may be illegible in electronic image products. Images are produced from the best available original document. 


\section{TABLE OF CONTENTS}

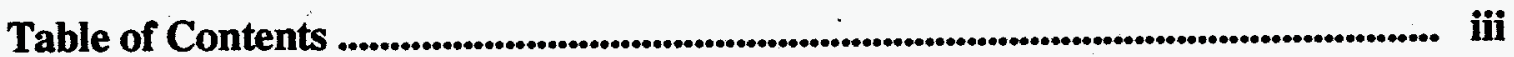

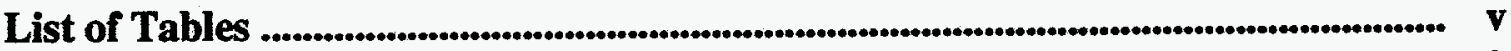

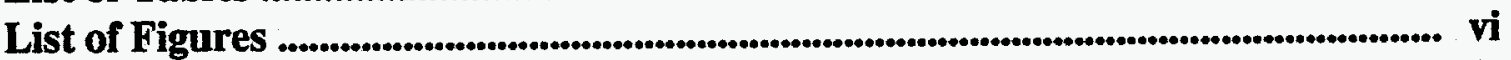

Acronyms, Definitions and Symbols ............................................................................... vii

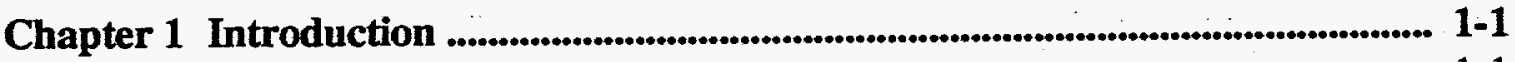

1.1 Purpose ............................................................................................... $1-1$

1.2 Scope …........................................................................................... $1-1$

1.3 Facility Description ..................................................................................... $1-1$

1.4 Program Objectives .................................................................................. $1-4$

1.5 Program Implementation ............................................................................... $1-4$

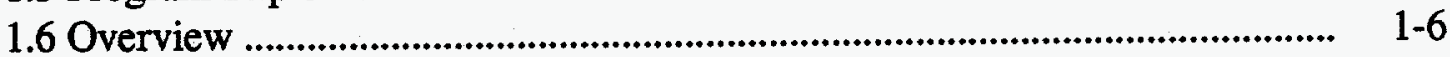

Chapter 2 Effluent Monitoring ................................................................................ 2-1

2.1 Introduction ............................................................................................. 2-1

2.2 Radionuclides Released to Air .................................................................... 2-1

2.2.1 Rationale ................................................................................... 2-1

2.2.2 Stack monitoring equipment ............................................................ 2-2

Collection and monitoring of particulate samples ............................ 2-2

Collection and monitoring of tritium samples ................................... 2-5

Provisions for redundancy ............................................................... 2-5

2.2.3 Sample collection and analysis ......................................................... 2-6

Particulates ............................................................................... 2-6

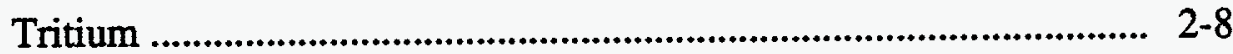

2.2.4 Planned improvements for stack monitor systems .............................. 2-. $2-8$

2.3 Radionuclides Released to Surface Water ....................................................... 2-9

2.3.1 Liquid effluent sources ....................................................................... 2-9

2.3.2 Rationale ...................................................................................... $2-9$

2.3.3 Liquid effluent sampling equipment ................................................... 2-11

2.3.4 Sample collection and analysis ....................................................... 2-11

2.4 Nonradiological Releases to Air ................................................................ 2-13

2.5 Nonradiological Releases to Surface Water ................................................ 2-15

2.5.1 NPDES monitoring requirements .................................................... 2-15

2.5.2 NPDES sampling locations and descriptions ..................................... 2-26

2.5.3 Procedures for sample collection and analysis .................................. 2-27

2.6 Data Management and Quality Assurance .................................................... 2-27

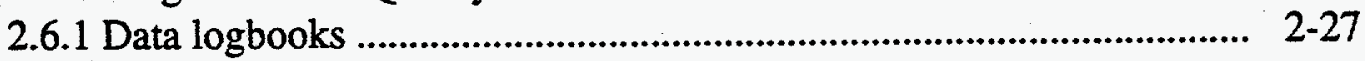

2.6.2 Quality assurance ......................................................................... 2-28 


\section{TABLE of CONTENTS (Con'd)}

Chapter 3 Meteorological Monitoring ....................................................................... 3-1

3.1 Rationale ........................................................................................ 3-1

3.2 Instrumentation ...................................................................................... 3-1

Primary tower ............................................................................................. 3-1

Secondary tower .................................................................................... 3-1

Atmospheric stability measurements ....................................................... 3-1

3.3 Data Management ............................................................................................ 3-2

3.4 Routine Releases ......................................................................................... 3-2

3.5 Emergency Response Capabilities ................................................................. 3-2

3.5.1 Atmospheric Release Advisory Capability (ARAC) ............................ 3-2

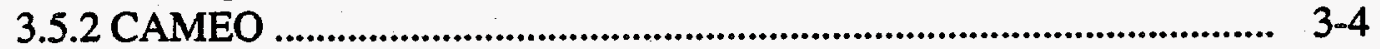

3.6 Quality Assurance Procedures and Responsibilities ......................................... 3-5

3.6.1 Instrument calibration and maintenance .............................................. 3-5

3.6.2 Training ................................................................................... $3-5$

3.6.3 Audits .................................................................................................

Chapter 4 Environmental Surveillance ............................................................................. 4-1

4.1 Ambient Air ....................................................................................... 4-1

4.1.1 Program objectives ................................................................................... 4-1

4.1.2 Operational specifications ..................................................................... 4-1

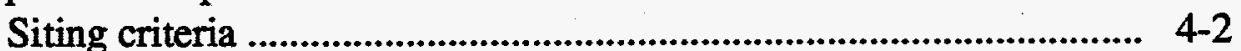

Plutonium sample collection and analysis .......................................... 4-4

Particulate load determinations .......................................................... 4-5

Tritium sample collection and analysis .............................................. 4-5

4.2 Surface Water and Sediment ......................................................................... 4-6

4.2.1 Program objectives ................................................................................ 4-6

4.2.2 Sample collection and analysis .......................................................... 4-6

4.3 Aquatic Biota .................................................................................... 4-8

4.4 Foodstuffs and Vegetation ................................................................................ 4-9

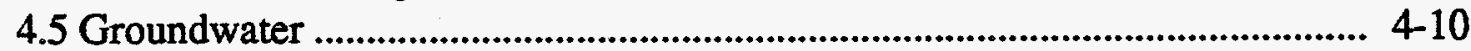

4.5.1 Introduction .................................................................................. 4-10

4.5.2 History .......................................................................................... 4-10

4.5.3 Groundwater sources .................................................................... 4-11

4.5.4 Groundwater monitoring network .................................................... 4-11

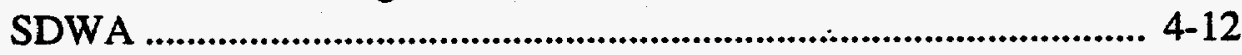

RCRA compliance monitoring and surveillance ............................... 4-12

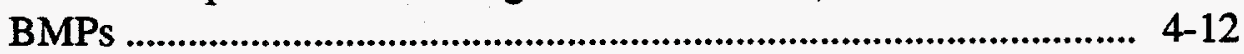

4.5.5 Methods and procedures .................................................................... 4-17

4.6 Multi-Media Quality Assurance Programs ................................................... 4-17

4.6.1 EML QA program .............................................................................. 4-. 4

4.6.2 Internal QA program ............................................................................. 4-17

4.6.3 Sample tracking procedures and data management .............................. 4-18 


\section{TABLE of CONTENTS (Con'd)}

Chapter 5 Dose Calculations 5-1

5.1 Exposure Routes $5-1$

5.2 Dose Estimates Based on Measured Concentrations ...................................... 5-2

5.3 Dose Estimates for NESHAPs Compliance .................................................. 5-4

Chapter 6 Preparation and Disposition of Reports ...................................................... 6-1

Chapter 7 References

\section{LIST OF TABLES}

Table 2-1 Radionuclides monitored at each Mound Plant stack ................................ 2-2

Table 2-2 Physical data for radionuclide-emitting stacks ........................................... 2-4

Table 2-3 Radiological criteria for emission monitoring ......................................... 2- 2-7

Table 2-4 Radionuclide sampling and analysis of onsite liquid effluents ................. 2-11

Table 2-5 Nonradiological atmospheric emission sources ..........................................2-14

Table 2-6 NPDES permit data ….................................................................................2-17

Table 4-1 Procedures for surface water and sediment sample collection and

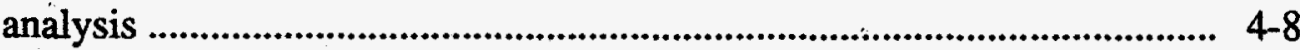

Table 4-2 Vegetation and foodstuffs sampling locations ........................................... 4-9

Table 4-3 BMP sampling of wells and water supplies for radiological constituents ......................................................................................... 4-15

Table 5-1 Factors used to calculate CEDEs ............................................................. 5-3

Table 5-2 CAP-88 input data ...................................................................................... 5-4

Table 6-1 Applicable reporting requirements ....................................................... 6-2 


\section{LIST OF FIGURES}

Figure 1-1 Location of the Mound Plant ............................................................ 1-2

Figure 1-2 Mound site topography ....................................................................... 1-3

Figure 1-3 Organizational elements of EG\&G Mound ................................................. 1-5

Figure 1-4 Organizational elements of the Dayton Area Office ................................... 1-5

Figure 2-1 Locations of radiological stacks ................................................................. 2-3

Figure 2-2 Liquid effluent sampling locations for radionuclides ................................ 2-10

Figure 2-3 NPDES sampling locations .........................................................................2-16

Figure 3-1 ARAC-generated graphics: simulated plume …....................................... 3-3

Figure 3-2 CAMEO-based site map ............................................................................. 3-4

Figure 4-1 Offsite air sampling locations ...................................................................... 4-2

Figure 4-2 Onsite air sampling locations ...................................................................... 4-3

Figure 4-3 Sampling locations for river water, pond water, and sediments ................ 4-7

Figure 4-4 Groundwater monitoring and surveillance sampling locations ................. 4-13

Figure 4-5 Additional groundwater sampling locations ............................................. 4-14

Figure 5-1 Exposure pathways for dose calculations .................................................. 5-1 


\section{ACRONYMS, DEFINITIONS, AND SYMBOLS}

ARAC indicates the Atmospheric Release Advisory Capability, a service of Lawrence Livermore National Laboratory.

BMP indicates a best management practice.

BTU is the abbreviation for british thermal unit.

BVA indicates the Buried Valley aquifer.

CAM indicates a continuous air monitor.

CEDE indicates a committed effective dose equivalent. A CEDE is the sum of the committed dose equivalents to various tissues in the body, each multiplied by the appropriate weighting factor.

CERCLA represents the Comprehensive Environmental Response, Compensation, and Liability Act, commonly referred to as Superfund.

CFM is the abbreviation for cubic foot per minute.

CFR indicates the Code of Federal Regulations.

Composite refers to a sample composed of two or more individual samples. Individual samples are frequently collected from a given area or medium and then combined to generate a "composite" sample of that area or medium.

CWA indicates the Clean Water Act and its amendments.

DAO indicates the Dayton Area Office of the U.S. Department of Energy.

D\&D indicates decontamination and decommissioning.

DOE indicates the U.S. Department of Energy.

DPM indicates a disintegration per minute.

EDE indicates an effective dose equivalent. AnEDE is the summation of the products of the dose equivalents received by tissues of the body and tissue-specific weighting factors.

Effluent is any untreated or treated liquid or gas point source emission from a site or facility.

EML indicates the Department of Energy's Environmental Monitoring Laboratory. 


\section{ACRONYMS, DEFINITIONS, AND SYMBOLS (con'd)}

EMP indicates the Environmental Monitoring Plan, a requirement of DOE Order 5400.1.

EOC indicates the Emergency Operations Center.

EPA indicates the U.S. Environmental Protection Agency.

ER represents environmental restoration.

ET\&M indicates the Environmental Technology \& Monitoring Section of EG\&G Mound Applied Technologies.

GWPMPP indicates the Groundwater Protection Management Program Plan, a requirement of DOE Order 5400.1 .

Inline indicates a monitoring system in which the detector or sample collector is located directly in the effluent stream.

Ionization chamber is a radiation detection unit that quantifies radionuclide concentrations by measuring the electrical current generated when incident radiation ionizes atoms of a gas or gas/air mixture stored in the chamber.

$\mathrm{KeV}$ is the abbreviation for kiloelectron volt.

LPM is the abbreviation for liter per minute.

MGD is the abbreviation for million gallons per day.

MREM is a unit for dose equivalent equal to $0.001 \mathrm{rem}$.

NESHAPs represents the National Emission Standards for Hazardous Air Pollutants.

NPDES represents the National Pollutant Discharge Elimination System. NPDES permits are issued by the federal or state EPA under the authority of the Clean Water Act.

OAC indicates the Ohio Administrative Code.

Offline indicates a monitoring system in which a sample of the effluent stream is conveyed to a detector or collector. -

OU indicates an operable unit.

QA indicates quality assurance. 


\section{ACRONYMS, DEFINITIONS, AND SYMBOLS (con'd)}

QC indicates quality control.

QAPP indicates a Quality Assurance Project Plan.

RAPCA is the Regional Air Pollution Control Agency, a local regulatory agency responsible for enforcing air quality standards in southwest Ohio.

RCRA indicates the Resource Conservation and Recovery Act and its amendments.

REM is a unit for dose equivalent.

RI/FS represents a Remedial Investigation/Feasibility Study which is part of the CERCLA process.

SARA indicates the Superfund Amendments and Reauthorization Act.

SDWA indicates the Safe Drinking Water Act and its amendments.

SOP indicates a standard operating procedure.

TTO indicates total toxic organics.

TU is the abbreviation for toxicity unit.

VOC indicates a volatile organic compound. 


\subsection{INTRODUCTION}

\subsection{Purpose}

The purpose of this Environmental Monitoring Plan (EMP) is to describe the environmental monitoring and surveillance programs in place at Mound. The Plan is required by DOE Order 5400.1 (DOE, 1990). The programs described in the EMP are required by the DOE 5400 Order series and by the Environmental Regulatory Guide for Radiological Effluent Monitoring and Environmental Surveillance (DOE 1991a), referred to as the Regulatory Guide throughout this Plan.

\subsection{Scope}

This Plan sets forth the requirements for the routine environmental monitoring and surveillance programs established by Mound. Program elements in the following key areas are discussed:

- effluent monitoring,

- meteorological monitoring,

- environmental surveillance,

- laboratory procedures,

- quality assurance,

- dose calculations, and

- report preparation and disposition.

\subsection{Facility Description}

The Mound Plant is a government-owned facility operated by EG\&G Mound Applied Technologies for the U.S. Department of Energy (DOE). Mound began operations in 1949. Currently, the site is an integrated production, development, and research facility which supports DOE's weapon and energy related programs.

The Plant consists of 120 buildings on $1.24 \mathrm{~km}^{2}$ (306 acres) of land in Miamisburg, Ohio, approximately $16 \mathrm{~km}(10 \mathrm{mi}$ ) southwest of Dayton (Figure 1-1). The Great Miami River, which flows southwest through the city of Miamisburg, dominates the geography of the five-county region surrounding Mound. The river valley is highly industrialized. The rest of the region is predominately farmland, dotted with light industry and small communities.

The topography of the Plant is shown in Figure 1-2. Site elevations range from $216 \mathrm{~m}$ to $268 \mathrm{~m}$ ( $710 \mathrm{ft}$ to $880 \mathrm{ft}$ ) above sea level. No buildings in which radiological materials are processed are located below an elevation of $241 \mathrm{~m}$ ( $790 \mathrm{ft}$ ). The typical non-flood stage of the Great Miami River is $208 \mathrm{~m}$ ( $682 \mathrm{ft}$ ). The highest floodwater level postulated for the river basin is $216 \mathrm{~m}(710 \mathrm{ft})$, which is approximately the lowest elevation at the site. No buildings at the Mound Plant are located in a floodplain or in areas considered wetlands. 

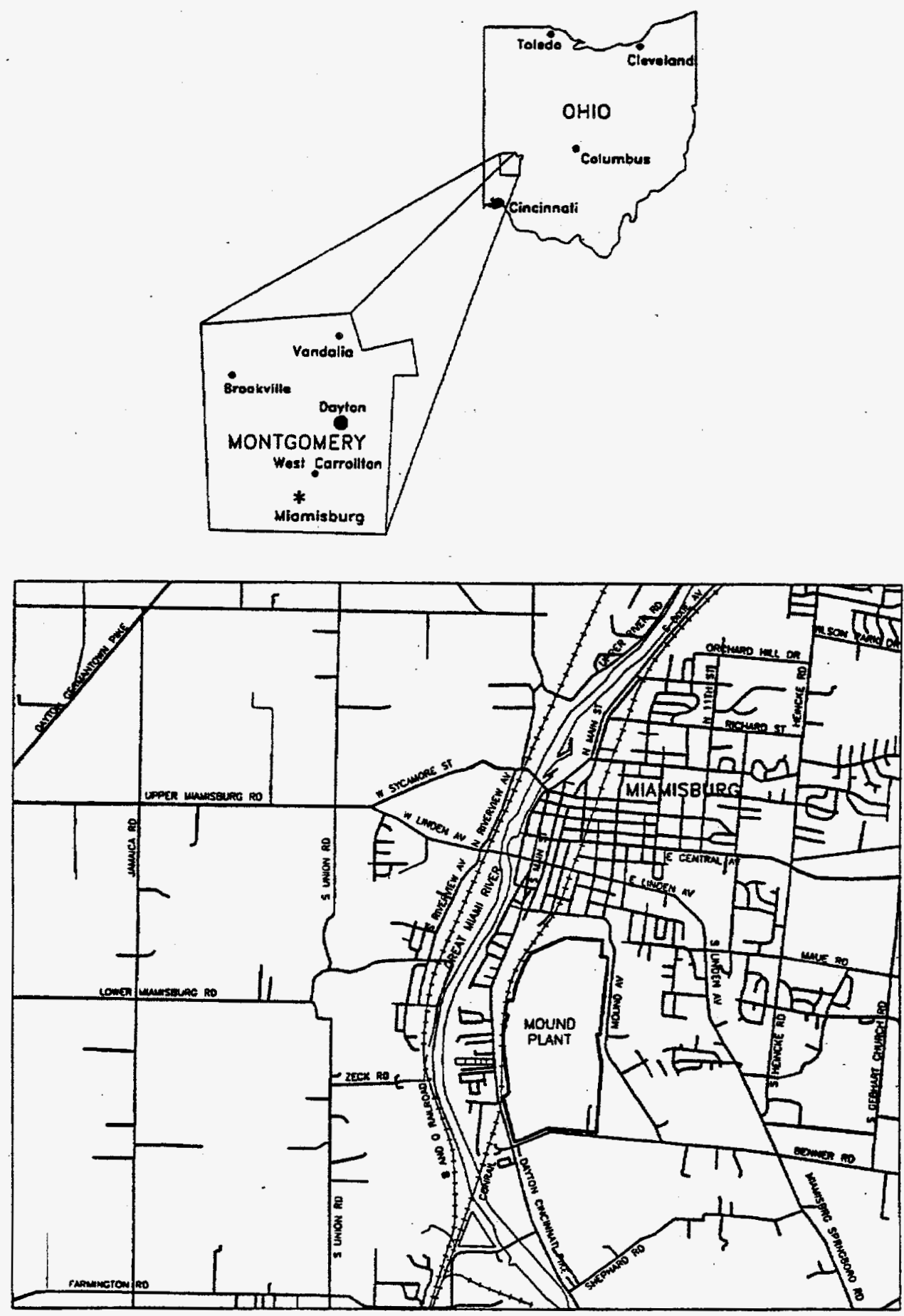

Figure 1-1. Location of the Mound Plant 


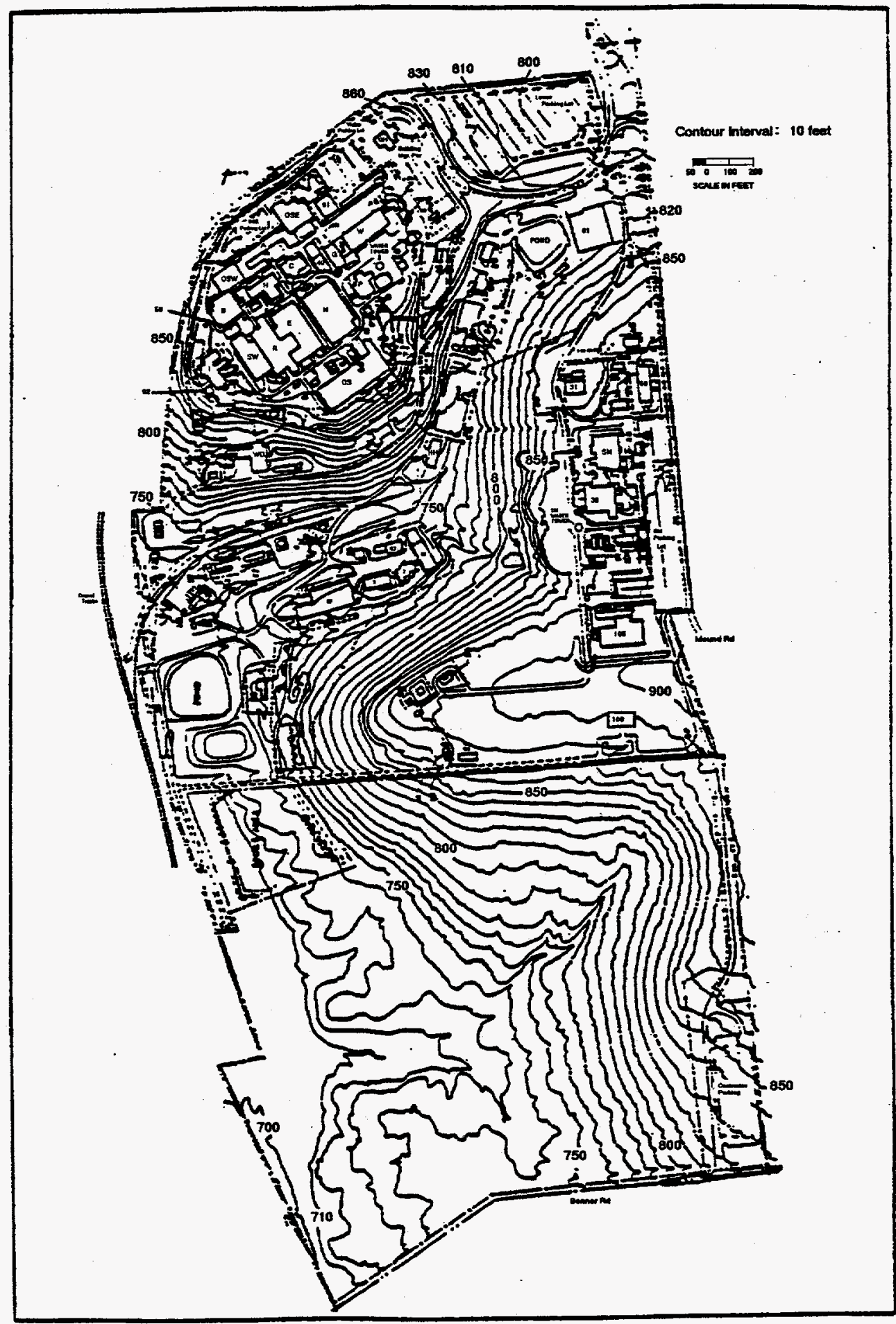

Figure 1-2. Mound site topography 
Mound was designated a Superfund site in 1989 under the Comprehensive Environmental Response, Compensation, and Liability Act (CERCLA). Under this designation, a multi-yearremedial investigation/ feasibility study (RI/FS) is in progress. The RI/FS continues a DOE Environmental Restoration (ER) program established in 1984. The ER program at Mound is charged with identifying, assessing, and remediating sites at which environmental releases occurred. The ER Program includes the assessment and remediation of contaminated groundwater.

Activities associated with the ER program are described in numerous documents and bulletins such as the Superfund Update. Additionally, the CERCLA Public Affairs Representative maintains a mailing list of individuals and agencies who wish to receive ER publications on a routine basis. Requests for copies of ER publications, and additions to the CERCLA mailing list, should be directed to Public Affairs/ CERCLA, EG\&G Mound.

\subsection{Program Objectives}

Key objectives of the environmental programs described in this Plan are to:

- demonstrate compliance with applicable environmental federal, state, and local regulations and DOE Orders,

- provide information to the public on plant releases and potential impacts of routine facility operation,

- obtain data to assess the consequences of unplanned releases,

- obtain data to identify long-term trends, and to

- demonstrate the validity of models used to estimate the transport and fate of radionuclides released from the plant.

\subsection{Program Implementation}

It is the responsibility of the Environmental Technology \& Monitoring (ET\&M) Section of EG\&G Mound Applied Technologies (Figure 1-3) to secure approval of this Plan. Approval is granted by the Manager, DOE/Albuquerque Operations Office. ET\&M is also charged with fully implementing the Plan. Plan implementation occurs under the direct supervision of the Environmental Branch of the Dayton Area Office of DOE (Figure 1-4).

DOE Order 5400.1 requires that the EMP be reviewed each year and updated every three years. The Environmental Technology \& Monitoring Section of EG\&G Mound is responsible for conducting the reviews and producing the updates. 


\section{EG\&G Mound Applied Technologies}

President and General Manager

Vice President, Environment, Safey \& Health

.

Senior Manager, Environmental Technology \& Monitoring

Environmental Monitoring

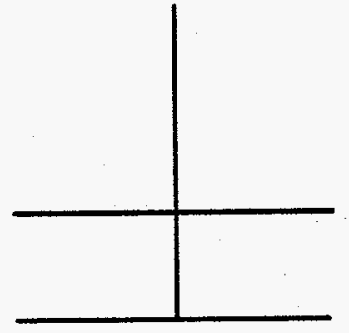

Permits and Compliance

Environmental Technology

Environmental Analysis and Bioassay

Figure 1-3. Organizational elements of EG\&G Mound

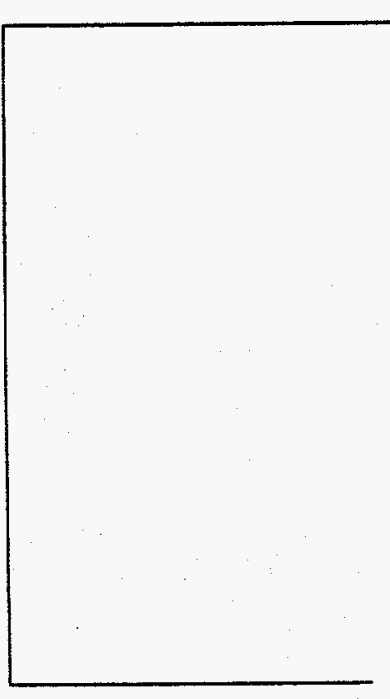

U.S. Department of Energy

Dayton Area Office

Area Manager

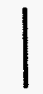

Deputy Area Manager

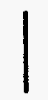

Chief, Environmental Branch

Environmental Program Management

Figure 1-4. Organizational elements of the Dayton Area Office 


\subsection{Overview}

The preceding sections described the general objectives of the Environmental Monitoring Plan for Mound. The goals of the Environmental Monitoring Plan (EMP) were established based on the requirements of DOE Order 5400.5 (DOE, 1993a) and the Regulatory Guide. (DOE Order 5400.5 is now a Proposed Rule for Radiation Protection of the Public and the Environment, Federal Register Vol. 58, No. 56, March 25, 1993.)

Chapter 2 of this Plan describes Mound's programs for monitoring liquid and airborne releases (effluents). The meteorological monitoring programs, and their roles in dispersion modeling for chronic and acute releases, are discussed in Chapter 3. Chapter 4 details the environmental surveillance programs in place at Mound. Chapters 5 and 6 of the Plan describe dose calculations and reporting requirements, respectively. 


\subsection{EFFLUENT MONITORING}

\subsection{Introduction}

Effluents produced by the Mound Plant consist of process exhaust air (stacks), process wastewater, sewage water, and storm water. Mound's effluent monitoring program is designed to show compliance with state and federal EPA standards, and to provide early warning of abnormal emissions so that timely corrective actions can be undertaken.

Operations at the Mound Plant began in 1949 for the production of nuclear weapons components. Currently, DOE activities at the plant include: (1) research, development, engineering, production, and surveillance of nuclear weapons components, (2) separation, purification, and sale of stable isotopes, (3) production and testing of heat source and fusion fuel systems for DOE customers, (4) support of programs in nuclear safeguards and waste management, (5) decontamination and decommissioning (D\&D) of surplus nuclear facilities, and (6) environmental restoration. It should be noted that activities involving weapons components are scheduled to be moved to other DOE sites beginning in FY1995.

For different periods of time throughout the history of operations at the Mound Plant, various radionuclides have been used. These nuclides include actinium-227, americium-241, bismuth-207, bismuth-210, cesium-137, cobalt-60, hydrogen-3, plutonium-237, plutonium-238, plutonium-239, plutonium-240, polonium-210, protactinium-231, radium-226, radon-222, strontium-90, thorium228 , thorium-229, thorium-230, thorium-232, uranium-233, uranium-234, uranium-235, and uranium238. In this chapter, Mound Plant monitoring programs for radionuclides released to air and water effluents are described. Discussions of sampling programs for nonradionuclides released to air and water effluents then follow.

\subsection{Radionuclides Released to Air}

The development of an airborne effluent radionuclide monitoring program is required by DOE Orders 5400.1 and 5400.5, and the DOE Regulatory Guide (DOE, 1991a). In addition to DOE requirements, the EPA has established regulations (40 CFR 61, Subpart H) governing radionuclide airborne emissions from DOE facilities.

\subsubsection{Rationale}

The Mound Plant continuously monitors ten exhaust air stacks (point sources) for radionuclides. The radionuclides monitored at each stack are identified in Table 2-1. The general location of each stack is shown in Figure 2-1. Sample collection and analysis are limited to those radionuclides currently in use, and those which could still exist in ductwork or other equipment, but are not currently used at Mound. If all traces (including ductwork, gloveboxes, etc.) of a particular radionuclide have been removed from Mound, or if the quantity or form of a particular radionuclide can not reasonably be expected to lead to an air emission, then it is not included in the stack monitoring program. Many smaller facilities at Mound fall into this category. Examples include analytical laboratories and some production areas where administrative limits govern the quantity of radionuclides present at any given time. 
Table 2-1. Radionuclides monitored at each Mound Plant stack

Stack

Bldg. 58 (HEFS)

NCDPF

SW Cave

T West

T East

HH

WD Low Risk

WD High Risk

WD SS

SM
Radionuclide(s)

Pu-238, Pu-239, 240, H-3

H-3

$\mathrm{Pu}-238, \mathrm{Pu}-239,240, \mathrm{H}-3, \mathrm{U}-233,234, \mathrm{U}-238$

$\mathrm{Pu}-238, \mathrm{Pu}-239,240, \mathrm{H}-3, \mathrm{U}-233,234, \mathrm{U}-238$

$\mathrm{H}-3$

H-3

$\mathrm{Pu}-238, \mathrm{Pu}-239,240$

Pu-238, Pu-239, 240

$\mathrm{Pu}-238, \mathrm{Pu}-239,240$

$\mathrm{Pu}-238, \mathrm{Pu}-239,240$

Physical data on each of the ten stacks are described in Table 2-2.

\subsubsection{Stack Monitoring Equipment}

The following section describes the instruments used at Mound to sample and monitor exhaust air continuously for gaseous and particulate radiological constituents. An alarm for elevated radionuclide emissions is in operation at each of these stacks, as required by the DOE Regulatory Guide, to provide timely warning and to signal the need for corrective action.

\section{Collection and Monitoring of Particulate Samples}

Samples of particulate emissions, plutonium or uranium, are collected by off-line alpha sampler/ monitor systems at the seven stacks identifed in Table 2-1. Alpha sampler/monitor systems consist primarily of sample transport lines, Eberline Alpha6 Continuous Air Monitors (CAMs), and vacuum pumps. The Alpha6 performs the dual function of collecting particulates on an internal filter and monitoring the presence of alpha particles on the surface of the filter. Counts from the real-time monitor are compared to a setpoint in the instrument's microprocessor. If the setpoint is exceeded, a local, audible and visual alarm is triggered.

The vacuum pumps draw a sample of the effluent at a rate of 22 to $80 \mathrm{~L} / \mathrm{min}$ to collect plutonium and uranium. The record filters used to trap the particles are 47-mm Millipore Type SM. The alarm setpoint is 50 counts per minute (cpm) during working hours, and $200 \mathrm{cpm}$ during evenings and weekends. 

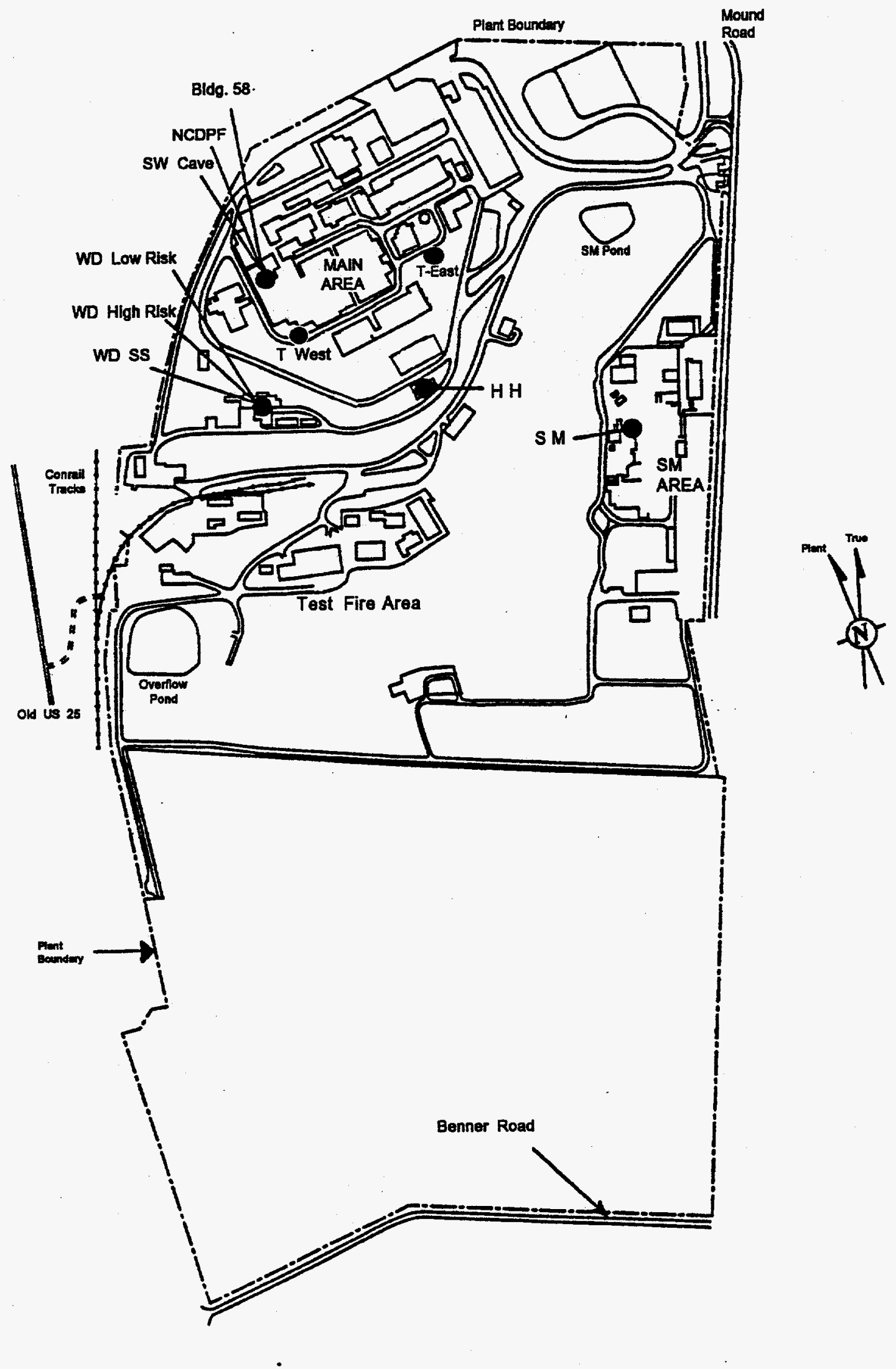

Figure 2-1. Locations of the radiological stacks 
Table 2-2. Physical data for the radionuclide-emitting stacks

\begin{tabular}{|c|c|c|c|c|c|c|c|c|c|c|}
\hline & $\begin{array}{l}\text { Bldg. } 58 \\
\text { (HEFS) }\end{array}$ & NCDPF & SW-Cave & T-West & T-East & $\mathrm{HH}$ & \begin{tabular}{|c|} 
WD \\
High Risk
\end{tabular} & $\begin{array}{c}\text { WD } \\
\text { Low Risk }\end{array}$ & WDSS & $\mathbf{S M}$ \\
\hline Stack Orientation & vertical & vertical & vertical & verrical & vertical & vertical & vertical & horizontal & vertical & vertical \\
\hline Stack Base Location & ground & roof & roof & ground & ground & roof & roof & roof & roof & ground \\
\hline Base Elevation ( $\mathrm{ft}$ ) & 878 & 910 & 909 & 880 & 880 & 837 & 831 & 834 & 803 & 883 \\
\hline $\begin{array}{l}\text { Number of Inlet } \\
\text { Ducts }\end{array}$ & 1 & 2 & 1 & 1 & 1 & 1 & 1 & 1 & 2 & 1 \\
\hline $\begin{array}{l}\text { Inlet Duct Elevation } \\
\text { (ft.) }\end{array}$ & 920 & 919 & 905 & 921 & 908 & 835 & 831 & 834 & 812 & 906 \\
\hline Building Exhausted & SW & SW & SW & $T \& R$ & $\mathrm{~T}$ & HH & WD & WD & WD & 38 \\
\hline $\begin{array}{l}\text { Primary Efftuent } \\
\text { Material }\end{array}$ & air & air & air & air & air & air & air & air & air & air \\
\hline $\begin{array}{l}\text { Effluent Max. } \\
\text { Temp. (deg. F) }\end{array}$ & 75 & 80 & 80 & 75 & 90 & 80 & 90 & 90 & 90 & 80 \\
\hline $\begin{array}{l}\text { Effluent Min. } \\
\text { Temp. (deg. F) }\end{array}$ & 60 & 60 & 60 & 6 & 60 & 60 & 60 & 60 & 60 & 60 \\
\hline $\begin{array}{l}\text { Effuent Ave. Rel. } \\
\text { Hum. (\%) }\end{array}$ & 50 & 50 & 50 & 50 & 50 & 50 & 65 & 65 & 65 & 50 \\
\hline $\begin{array}{l}\text { Effluent Pressure } \\
\text { (a) }\end{array}$ & atmos + & atmos + & atmos + & atmos + & atmos + & atmos + & $\operatorname{armos}+$ & atmos + & armos + & atmos + \\
\hline $\begin{array}{l}\text { Stack Material of } \\
\text { Construction }\end{array}$ & steel & steel & steel & brick & brick & brick & steel & steel & steel & brick \\
\hline Exit Elevation (ft.) & 1029 & 1011 & 1028 & 1076 & 1075 & 912 & 843 & 840 & 839 & 1078 \\
\hline $\begin{array}{l}\text { Exit Diameter } \\
\text { (inches) }\end{array}$ & 76 & 27 & 36 & 96 & $n$ & 66 & 20 & 44 & 13 & 72 \\
\hline $\begin{array}{l}\text { Normal Flow Rate } \\
\text { (CFM) }\end{array}$ & 100,000 & 14,500 & 16,400 & 124,000 & 35,000 & 6,490 & 4,000 & 16,000 & 1,000 & 30,000 \\
\hline Exit Area (sq. ft.) & 33.2 & 3.1 & 7.07 & 50.3 & 28.3 & 23.8 & 2.2 & 10.6 & 0.92 & 28.3 \\
\hline $\begin{array}{l}\text { Normal Exit Vel. } \\
\text { (FPM) }\end{array}$ & 3012 & 4677 & 2320 & 2465 & 1237 & 273 & 1818 & 1509 & 1987 & 1060 \\
\hline $\begin{array}{l}\text { Sampling Elevation } \\
\text { (ft.) }\end{array}$ & 966 & 932 & (b) & (c) & 890 & 878 & 832 & (d) & 815 & 984 \\
\hline
\end{tabular}

(a) atmos + indicates that the air pressure inside the stack is slightly above atmospheric pressure.

(b) The stacks monitors for the SW cave north stack are not on the stack. The sample for the alpha CAM is taken from the stack fan inlet plenum. The sample for the tritium bubbler and the ion chambet are taken at a branch duct (SW-219 exhaust) that feeds into the stack.

(c) The monitors and samplers for the T-West stack are locaced on four separate branch ducts which eventually feed into the stack. There are no monitors on the stack at this time. The branch duct designations and the types of monitors are as follows: 1) E-22; T-Bldg. room 99; tritium bubbler and ion chamber, 2) E-31B; T-Bldg- room 99; tritium bubblers and ion chamber, 3) R-127; $R$ Bldg. room 127; tritium bubbler and ion chambers, and 4) R Bldg. main exhauss; alpha continuous air monitors (CAMs).

(d) The WDA Low Risk Stack is horizontal, so sampling elevation is meaningless. The samples for the alpha CAMs are taken 17.5 feet from the stack inlet. 
The concentration of Pu-238 that would trigger an immediate response by the Alpha6 is approximately $5.8 \times 10^{-8} \mu \mathrm{Ci} / \mathrm{cm}^{3}$. The maximum count rate for the Alpha6 is approximately one half million counts per minute. The monitor also features an internal mass flow meter for concentration calculations.

\section{Collection and Monitoring of Tritium Samples}

Bubblers. As shown in Table 2-1, six stacks are monitored for tritium. These stacks are continuously sampled by an offline instrument consisting of an ethylene glycol bubbler train, a heated palladium catalyst, a vacuum pump, and a sample mass flow controller. All of these instruments were designed and assembled at Mound. They are described in the EG\&G Mound Technical Manual 80030, Operation 2119. The bubbler train consists of six 20-mL Packard liquid scintillation vials, each filled with 10 $\mathrm{mL}$ of ethylene glycol.

The effluent sample passes in series through the first three vials (A,B,C) which trap essentially all of the tritium oxide. The sample then passes through the heated palladium catalyst which oxidizes $99 \%+$ of the elemental tritium into tritium oxide. By directing the catalyzed sample in series through the final three glycol vials $(\mathrm{D}, \mathrm{E}, \mathrm{F})$, the newly created oxides are also trapped. The "clean" sample then exits the instrument after passing through the control valve and pump. This sampling technique effectively differentiates between tritium oxide and elemental tritium, which is important because the radiotoxicity of tritium oxide is orders of magnitude larger than that of elemental tritium. Bubblers make it possible to detect tritium concentrations as low as $1 \times 10^{-11} \mu \mathrm{Ci} / \mathrm{mL}$. The sampling flow rate for the bubbler train is controlled at $150 \mathrm{cc} / \mathrm{min}$. The palladium catalyst temperature is maintained at $475^{\circ} \mathrm{C}$.

Tritium Monitors. The bubbler assemblies described above provide an excellent means of determining very low tritium concentrations in stack effluents as well as differentiating between elemental tritium and tritium oxide. The bubblers, however, do not provide real-time release data. For real-time monitoring purposes, ionization chambers are used; they provide instant measurements of tritium concentrations, and have audible alarms to indicate increases in tritium emissions.

The chambers are used to monitor continuously all rooms, gloveboxes, ducts and stacks which have the potential to release tritium. The unit used for most of the stacks is a 2-liter ion chamber. The range is 0 to $20,000 \mu \mathrm{Ci} / \mathrm{m}^{3}$ with a resolution of $1 \mu \mathrm{Ci} / \mathrm{m}^{3}$. Alarm levels are set at 10 to $30 \mu \mathrm{Ci} / \mathrm{m}^{3}$ depending on the stack being monitored. The sample flow rates through the ion chambers are set manually, and range from 4 and 11 LPM depending on location. Sample air is continuously pulled through the ion chamber by an external vacuum pump.

\section{Provisions for Redundancy}

The use of backup generator circuits, uninterruptable power supply (UPS), and redundant equipment has been inconsistently applied to the stack monitor systems at Mound. With the 1990 amendments to the Clean Air Act, stack monitors became a high priority, and major projects (Section. 2.2.4) have been funded which will ensure reliability and redundancy for stack monitors. 


\subsubsection{Sample Collection and Analysis}

Mound monitors ten stacks continuously for radiological effluents. Mound is required by NESHAPs and the DOE Regulatory Guide to sample continuously point sources that could result in doses greater than $0.1 \mathrm{mrem} / \mathrm{y}$ ear to the most exposed member of the public. Stacks which have potential doses below $0.1 \mathrm{mrem} /$ year require periodic measurements to verify low emissions. More detailed criteria for airborne effluent radionuclide monitoring are listed in Table 2-3.

Particulates. Particulate sample filters for stacks are collected and the alpha activity is counted daily. An analysis of a composite sample is performed monthly.The following operations are specific analytical procedures used by Mound personnel for airborne radionuclide particulate samples. All are part of the Mound Technical Manual MD-80030, Environmental Analytical Procedures, and are incorporated by reference into this Plan.

Operation 1110, Plutonium in Air by Acid Leach Method, is used for the analysis of air filters for plutonium. Levels greater than $0.1 \mathrm{dpm}$ (disintegrations per minute) can be measured with an average chemical yield of about $60 \%$. The procedure consists of heating the filter(s) at $550^{\circ} \mathrm{C}$ for 8 to 16 hours, dissolution of the plutonium with a nitric acid leach, separation of the plutonium by anion exchange chromatography and electrodeposition, and measurement of the plutonium isotopes by alpha spectrometry. After adding Pu-242 tracer to the sample, it is heated for at least 8 hours at $550^{\circ} \mathrm{C}$. After cooling to room temperature, the sample is leached with nitric acid. This leachate is filtered and then passed through an anion exchange column which adsorbs the plutonium. The plutonium is eluted by reduction to Pu(III) with the iodide ion. The plutonium is electrodeposited onto stainless steel slides for counting by alpha pulse height analysis using a silicon surface barrier detector.

Operation 1112, Plutonium in Air by Acid Dissolution Method, is applicable to the analysis of one to ten 4-inch diameter polystyrene or glass-fiber air filters or plutonium at levels greater than $0.1 \mathrm{dpm}$. The method can be used for analysis of nonrefractory plutonium and is also applicable to samples containing certain refractory forms of plutonium. The present procedure involves decomposing the sample by heating at $600^{\circ} \mathrm{C}$ followed by a nitric acid-hydrofluoric acid dissolution. Boric acid is added to complex the fluoride ion, and a iron hydroxide precipitation is performed to coprecipitate the plutonium. This hydroxide precipitate is dissolved in nitric acid, and the plutonium is oxidized to plutonium (IV) with sodium nitrite for subsequent adsorption onto an anion exchange column. Thorium is removed from the column with hydrochloric acid and the plutonium is eluted by reduction onto stainless steel slides and is measured by alpha pulse height analysis using a silicon surface barrier detector. Concentrations of Pu-238 and Pu-239,240 and the Pu-242 tracer recovery can be calculated from the counts observed for each alpha peak energy and the counter efficiency.

Operation 3123, Uranium in Air by an Acid-Leach Method, is used for analysis of air filters for uranium. Levels greater than $0.1 \mathrm{dpm}$ can be measured with an average chemical yield of about $70 \%$. This procedure consists of heating the filter(s) at $550^{\circ} \mathrm{C}$ for a minimum of 4 hours. Dissolution of the uranium with a hydrochloric acid leach, and separation of the uranium by anion exchange chromatography then follow. The uranium is electrodeposited onto stainless steel slides for counting by alpha spectrometry. 
Table 2-3. Radiological criteria for emission monitoring

Calculated Maximum Dose from Emissions in a Year to Members of the Public:

EDE $\geq 1$ mrem

0.1 mrem $\leq$ EDE $<1$ mrem

EDE $<0.1$ mrem

\section{Minimum Emission Monitoring Criteria}

1) Continuously monitor emission points that could contribute $0.1 \mathrm{mrem}$ in a year

2) Identify radionuclides that contribute $10 \%$ of the dose

3) Determine accuracy of results (\% accuracy and \% confidence level)

4) Conduct a confirmatory environmental survey annually

\section{or monitor at the receptor:}

1) Obtain prior approval from EPA

2) Continuously sample air at receptor

3) Collect and measure radionuclides contributing 1 mrem (EDE) above background

4) Establish sample density sufficient to estimate dose to critical receptor given typical variability of meteorological conditions

1) Continuously monitor emission points that could contribute 0.1 mrem in a year

2) Identify radionuclides that contribute $10 \%$ or more of the dose

3) Conduct confirmatory effluent monitoring at emission points where possible

4) Conduct periodic confirmatory environmental surveys

1) Take periodic confirmatory measurements

2) Test to determine need to monitor by calculating dose for normal operation, assuming that the emissions controls are inoperative

3) Conduct periodic confirmatory environmental surveys

Source: DOE Regulatory Guide (DOE, 1991a). 
Operation 3307, Uranium in Soil and Air by Acid Dissolution Method, is applicable to the determination of uranium isotopes in air filter samples. It has been applied to both glass fiber and microsorban (polystyrene) air filters. Analysis of one to ten 4-inch diameter microsorban or glassfiber air filters can be performed with the present procedure. The sensitivity of the method is estimated to be about $0.1 \mathrm{dpm} /$ filter for air filter samples. The procedure involves a nitric acid-hydrofluoric acid dissolution, coprecipitation of uranium with iron hydroxide, separation of uranium by anion exchange, and electrodeposition of the uranium followed by alpha pulse height analysis.

\section{Tritium}

For the tritium samples, analytical results are generated daily. The first bubbler vial (A) of the tritium oxide collectors and the first vial (D) of the elemental tritium collectors are analyzed daily, then composited for monthly analyses. Bubblers B, C, E, and F are collected weekly, then composited for monthly analyses. During emergency episodes, unusual occurrences, or other events that could significantly increase emissions at a source, Mound performs laboratory analyses as soon as reasonably possible on effluent samples from the affected area(s).

The following analytical procedure for air effluent tritium is incorporated by reference into this Plan. Operation 2119, Tritium Gas and Tritiated Water in Stack Effluent, describes the discriminating tritium bubbler instrument in detail, the bubbler vial collection procedure, and the vial lab analysis procedure. The analytical procedure consists essentially of mixing an aliquot of the bubbler glycol with scintillation cocktail and counting the mixture in a liquid scintillation spectrometer.

\subsubsection{Planned Improvements for Stack Monitor Systems}

The Mound Plant is currently undertaking a major project to modify and rebuild the WD High Risk, WD Low Risk, T-West, SW Cave, and Bldg. 58 radionuclide stack monitors/samplers. The modifications will include installation of isokinetic sampling equipment, stack and sample line mass flow meters, redundant equipment, field calibration ports, auto-dialer alarm system, and generator backup. The design of the project will address applicable U.S. EPA regulations as well as DOE Orders. The remaining stack systems are not included in these upgrades because their potential emissions fall below the EPA threshold of $0.1 \mathrm{mrem} / \mathrm{year}$, and their current monitor systems are adequate.

The project modifications will include combining the WD High Risk stack into the WD Low Risk exhaust system through ductwork modifications. T Building's two existing monitor stations (E-22 and E-31B) on its west exhaust and R Building's two existing monitor stations (R-Main and R-127) will be combined into one station located at the West Stack. A new sampling shed will be built at the base of the T-West Stack to house the monitoring equipment. For the SW and WD stacks, the monitoring equipment will be located inside existing rooms. 
This project will also address many QA/QC items such as the writing of operating and maintenance procedures, the purchase of spare parts and calibration equipment, and the training of operators. The completion of this project is the responsibility of the EG\&G Mound Environmental Technology Group. This project is also the focal point of a Federal Facilities Compliance Agreement which has been negotiated with Region 5 of the U.S. EPA.

\subsection{Radionuclides Released to Surface Water}

The Mound Plant has the potential to discharge low levels of radionuclides to water as well as to air. Since there are no wastewater discharges which could reasonably be expected to contain high levels of radioactive materials, real-time monitors with alarms are not necessary for any of Mound's liquid effluent streams. However, an extensive program of effluent and surface water sampling has been in place at the facility for many years. (Ponds and other types of surface waters are not considered liquid effluents, their sampling is covered in Chapter 4, Environmental Surveillance.)

DOE Orders 5400.1 (DOE, 1990), 5400.5 (DOE, 1993a), and the DOE Regulatory Guide (DOE, 1991a) provide concentration limits for radionuclides to minimize public and environmental radiation doses. The DOE has also set standards regarding radionuclide dose limits to the public, and established guidelines for effluent monitoring programs. These requirements help ensure that effluents from DOE facilities have minimal impact on human health and the environment.

\subsubsection{Radionuclides in Liquid Effluents}

Mound Plant personnel sample effluent water for radionuclides at thirteen locations as shown on Figure 2.2. Three of these locations (STA-1, STA-2, and SD-E) are outfalls where the effluents exit the facility boundary, and then proceed a short distance before entering the Great Miami River. Samples drawn from these three outfalls are also analyzed for NPDES parameters (Section 2.5). The other ten water effluents are arterials to the three outfalls. Five are storm sewers, and five are sanitary sewers leading to the Sanitary Disposal (SD) Plant. Storm sewer arterials have "T-_" designations; sanitary sewer arterials are identified by "D-.."

In addition to the locations noted above, six samples are collected weekly in Buildings T and SW from closed-loop, process cooling water systems. These samples analyzed for tritium, but are not effluent samples.

\subsubsection{Rationale}

The historical and current radionuclides used in operations at the Mound Plant were identified in Section 2.2. Generally, water effluents are anatyzed for the same radionuclide contaminants as are the stack effluents. Table 2.4 summarizes the routine radiological monitoring of onsite liquid effluents at Mound. 


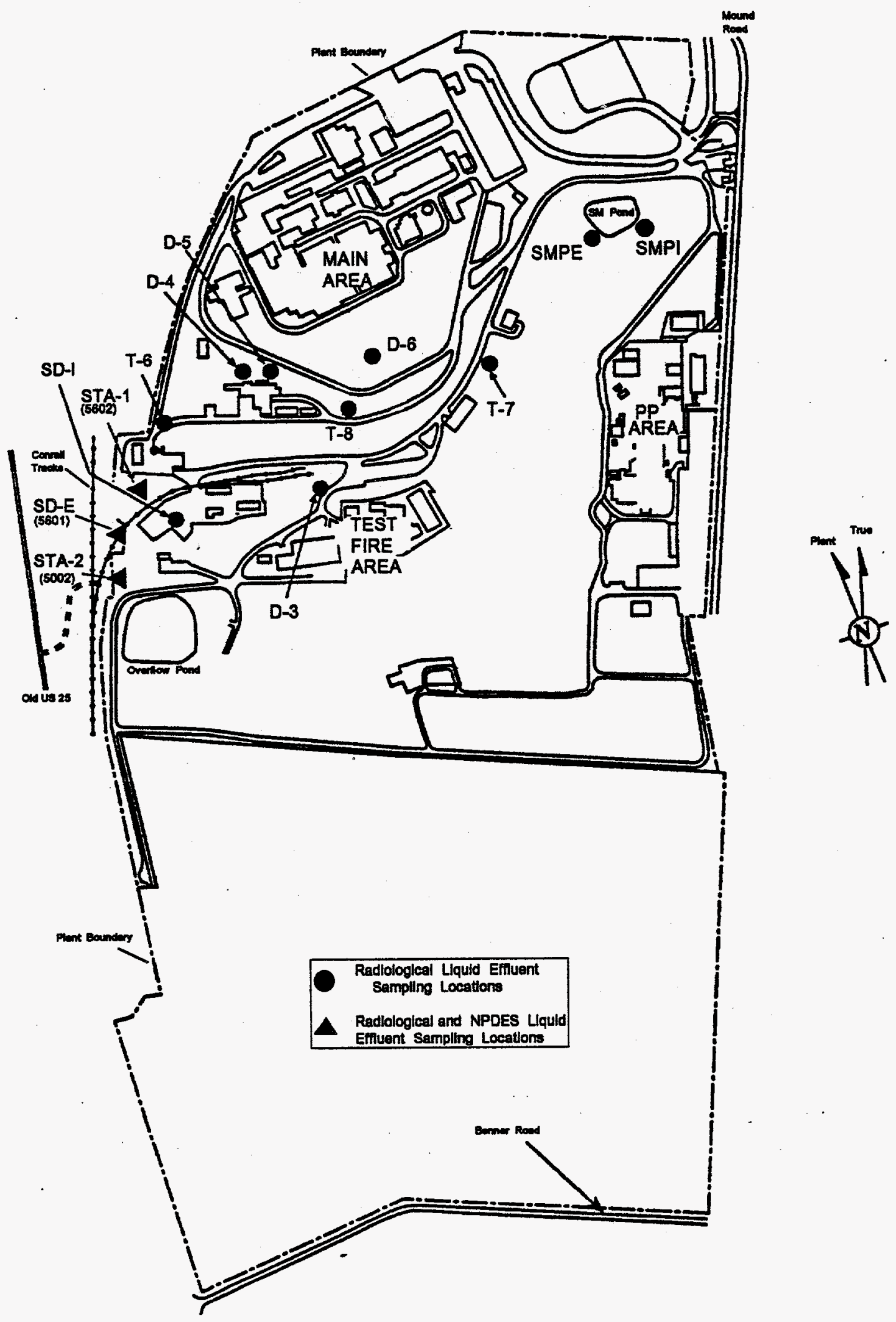

Figure 2-2. Liquid effluent sampling locations for radionuclides • 
Table 2-4. Radionuclide sampling and analysis of onsite liquid effluents

\begin{tabular}{|c|c|c|}
\hline Location & Erequency & Analysis \\
\hline $\begin{array}{l}\text { STA-1 }(5602) \\
\text { STA-2 }(5002) \\
\text { SD-E }(5601)\end{array}$ & $\begin{array}{l}\text { Daily } \\
\text { Daily } \\
\text { Daily }\end{array}$ & $\begin{array}{l}\text { Gross alpha \& tritium } \\
\text { each day. Pu-238, Pu } \\
\text { and U-238 are evaluate } \\
\text { composite samples. }\end{array}$ \\
\hline SD-I & Daily & Gross alpha \& tritium \\
\hline D-3 & Daily & Gross alpha \& tritium \\
\hline$D-4$ & Daily & Gross alpha \& tritium \\
\hline D-5 & Daily & Gross alpha \& tritium \\
\hline D-6 & Daily & Gross alpha \& tritium \\
\hline$T-6$ & Daily & Gross alpha \& tritium \\
\hline T-7 & Daily & Gross alpha \& tritium \\
\hline $\mathrm{T}-8$ & Daily & Gross alpha \& tritium \\
\hline SMPI & Daily & Gross alpha \& tritium \\
\hline SMPE & Daily & Gross alpha \& tritiun \\
\hline
\end{tabular}

\subsubsection{Liquid Effluent Sampling Equipment}

Flow-proportional, 24-hour, composite samples and grab (manual) samples are collected from locations STA-1, STA-2, and SD-E. These three locations are also sampled for nonradioactive parameters under the Mound NPDES program as described in Section 2.5. The same equipment is used for both programs. Time-proportional composite samples and grab samples are collected from the arterial effluents. The automatic sampling and flow measurement equipment is described more fully in Section 2.5.1.

\subsubsection{Sample Collection and Analysis}

At the three outfalls (STA-1, STA-2, and SD-E) where water effluents exits the plant boundary, samples are collected four times a week. Three of the collections are for 24-hour sampling periods, and one collection is a 96-hour weekend sampling period. Samples are analyzed four times a week for tritium and composited and analyzed weekly for Pu-238, Pu-239,240, U-233,234, and U-238. Separate aliquots are removed for each parameter requiring analysis.

Five onsite sanitary sewer arterials leading to the Sanitary Disposal Plant also are sampled by automatic samplers as 24-hour composites. The composite samples are collected daily and analyzed for tritium and gross alpha. Other onsite sampling locations for effluent water are the five storm sewer arterials that lead to the outfalls. Samples are collected daily as a 24 -hour composite by automatic samplers. The parameters measured are tritium and gross alpha.

The Mound Technical Manual MD-80030 describes analytical procedures for all effluent and environmental media including water. The operations on the following pages are the specific procedures for determining radionuclide content in liquid effluent samples; all are incorporated by reference into this EMP. 
Operation 0220, Gross Alpha Radioactivity in Water Samples, describes the measurement of gross alpha particle activity in environmental water samples. The method is a screening technique for monitoring onsite arterial streams which flow into Mound's effluents. Because the radioactivity of the water component is not separated from that of the solid component, the concentration of solids is a limiting factor in the sensitivity of the method. The solids content of the slide on which the sample is deposited should not exceed $5 \mathrm{mg} / \mathrm{cm}^{2}$. In this procedure, an aliquot of a water sample is transferred quantitatively to a $17 / 8$-inch diameter stainless steel disk. The sample is dried under a heat lamp and then counted for alpha radioactivity in a $2 \pi$ gas flow proportional counter.

Operation 1201, Plutonium in Water by a Coprecipitation Anion Exchange Method, is applicable to the determination of $\mathrm{Pu}-238$ and $\mathrm{Pu}-239$ in filtered freshwater samples having volumes up to 50 liters. Concentrations as low as $0.02 \mathrm{pCi} / \mathrm{L}$ can be determined. If blanks and backgrounds are low enough, and if the samples are counted long enough, concentrations lower than $0.02 \mathrm{pCi} / \mathrm{L}$ can be determined. On a collaborative test of one-liter samples, Pu- 242 tracer recoveries averaged about $70 \%$. The procedure consists of coprecipitation, anion exchange separation and electrodeposition, followed by alpha pulse height analysis.

Operation 1272, Plutonium Activity in Liquid Effluents, is used for determining Pu-238 and Pu-239 in unfiltered effluents. This procedure is used to analyze volumes of four liters or less. The lower detection limit is approximately $0.02 \mathrm{pCi} / \mathrm{L}$ for a one-liter sample. Flow-proportional effluent samples are collected on a daily basis. A calculated aliquot is taken from each sample and combined for weekly analysis. This procedure consists of coprecipitation, anion exchange separation, and electrodeposition, followed by alpha pulse height analysis.

Operation 2261, Tritium in Environmental Water Samples, describes the preparation and screening of environmental water samples for tritium analysis using liquid scintillation spectroscopy. The method has a lower detection limit range of approximately $0.2-1.2 \mu \mathrm{Ci} / \mathrm{L}$. A $10-\mathrm{mL}$ environmental water sample is pipetted into a $25-\mathrm{mL}$ polyethylene counting vial containing $10 \mathrm{~mL}$ of scintillation solution. The sample vials are counted in a liquid scintillation spectrometer, configured to $0-18 \mathrm{keV}$, which has been calibrated and programmed to process automatically all samples and to prepare a report.

Operation 3240, Radiochemical Determination of Uranium Isotopes in Water, is used for the determination of uranium isotopes in water. The method is capable of detecting either soluble uranium or uranium that might be present in suspended matter in the water. The method has been tested on water samples having a volume as great as 20 liters. The lower detection limit is about $0.02 \mathrm{pCi} / \mathrm{L}$ for a one-liter sample counted for 1000 minutes. The water sample to be analyzed is acidified and U232 is added to serve as an isotopic tracer before any additional operations are carried out. The uranium is coprecipitated from the sample with ferrous hydroxide. This precipitate is dissolved in concentrated hydrochloric acid, or in concentrated nitric and hydrofluoric acids if the hydrochloric acid fails to dissolve the precipitate. The uranium is separated from other radionuclides by absorption on anion exchange resins from hydrochloric acid, followed by elution with hydrochloric acid. The uranium is finally electrodeposited onto a stainless steel disk for alpha pulse height analysis with a silicon surface barrier detector. 
Operation 3271, Uranium Activity in Liquid Effluents, is used for determining U-233,234 and U-238 in unfiltered effluents of four liters or less volume. The lower detection limit is approximately 0.03 $\mathrm{pCi} / \mathrm{L}$ for a one-liter sample counted for 1000 minutes. Flow-proportional effluent samples are collected on a daily basis. A calculated aliquot is taken from each sample and combined for a weekly analysis. This procedure consists of coprecipitation, anion exchange separation, and electrodeposition, followed by alpha pulse height analysis.

\subsection{Nonradiological Releases to Air}

The Mound Plant releases very small quantities of nonradiological constituents into the atmosphere. An extensive nonradiological air monitoring program is therefore not in use. Annual emission rates are calculated using a material balance approach. The releases are governed by State of Ohio EPA permits and regulations. This section describes the nature, quantity and permit (to operate or install) status of the primary nonradiological air emissions at the Mound Plant.

Currently, four plant operations have been granted "permit to operate" status by the State of Ohio. Two other operations have been registered with the Regional Air Pollution Control Authority (RAPCA), and approximately 140 small source permits have been filed with the Ohio EPA. The following section presents a brief description of the six primary sources. Table 2.5 summarizes the emissions data on these sources.

Powerhouse. During nominal operation, the Mound Power Plant burns natural gas. Natural gas burns cleanly; no opacity or sulfur dioxide monitors are required. If the supply of natural gas is interrupted, the plant burns fuel oil. This transition is a rare event which is exempted from the particulate and sulfur dioxide emission limits established by the State of Ohio (Ohio EPA Regulation 3745-17-10).

Paint Spray Booth. The regulated unit is an enclosed dry paint spray booth used for manual application of paint on furniture and miscellaneous equipment. Dry filter media are used to adsorb any air contaminants generated by this operation. Negligible amounts of air pollutants would be expected to leave this facility. Further, it is a condition of the permit that records listing the gallons of paint and thinner used each day be maintained for at least 2 years. These records are subject to inspection by employees of the federal and/or Ohio EPA.

Open-top Vapor Degreaser. The degreaser is fitted with covers and has vapor control equipment which automatically shuts off the sump heat when vapor levels exceed specified values. Because of these engineered containment structures and mechanisms, emissions of volatile organic compounds (VOCs) are negligible.

Open Burning of Explosives. DOE and EPA regulations recognize burning as the only viable disposal option for certain explosives handled by Mound. RAPCA has established a 50-1b/burn limit for such exercises. Also, Mound is prohibited from performing these activities during air alerts, warnings, or emergencies. 
Open Burning for Firefighter Training. For purposes of training its firefighters, Mound intentionally ignites diesel or unusable fuel, clean lumber, and/or paper. It is a condition of the permit that Mound use the least amount of fuel required to meet the training objectives. It is also a condition of the permit that no more than three burns/week occur and that no such training activities be conducted during air alerts, warnings, or emergencies.

Table 2-5. Nonradiological atmospheric emission sources

\begin{tabular}{|c|c|c|c|c|}
\hline Operation & Permit No. & Valid Through & Pollutant(s) & Emission Limit(s) \\
\hline Powerhouse & $\begin{array}{l}\text { N/A } \\
\text { registration status }\end{array}$ & $\mathrm{N} / \mathrm{A}$ & $\begin{array}{l}\text { Particulates } \\
\mathrm{SO}_{2}\end{array}$ & $\begin{array}{l}0.02 \mathrm{lbs} / 10^{6} \mathrm{BTU} \\
\text { input } \\
1.5 \mathrm{lbs} / 10^{6} \mathrm{BTU} \\
\text { input }^{\mathrm{b}}\end{array}$ \\
\hline Paint spray booth & 0857091196K001 & $11 / 26 / 95$ & Organics & $5000 \mathrm{lbs} / \mathrm{yr}$ \\
\hline $\begin{array}{l}\text { Open-top vapor } \\
\text { degreaser }\end{array}$ & $0857091196 \mathrm{~L} 002$ & $01 / 26 / 96$ & Organics & N/A ${ }^{d}$ \\
\hline $\begin{array}{l}\text { Gasoline Dispensing } \\
\text { Facility }\end{array}$ & $\begin{array}{l}\text { N/A } \\
\text { registration status }\end{array}$ & N/A & Organics & N/A \\
\hline $\begin{array}{l}\text { Open burning } \\
\text { (explosives disposal) }\end{array}$ & $\begin{array}{l}\text { N/A } \\
\text { letter permit }\end{array}$ & $\begin{array}{l}\text { 07/23/94 } \\
\text { (renewal requested) }\end{array}$ & Particulates & $\begin{array}{l}\leq 50 \text { lbs of } \\
\text { explosives/ } \\
\text { burn }^{\text {c,f }}\end{array}$ \\
\hline $\begin{array}{l}\text { Open burning } \\
\text { (firefighter training) }\end{array}$ & $\begin{array}{l}\text { N/A } \\
\text { letter permit }\end{array}$ & $\begin{array}{l}\text { Permanent } \\
\text { authorization }\end{array}$ & Particulates & $\leq 3{\text { burns} / \text { week }^{c}}^{c}$ \\
\hline
\end{tabular}

N/A = not applicable.

"Ohio EPA Regulation 3745-17-10, Restrictions on particulate emissions from fuel burning equipment, effective $06 / 14 / 91$.

'Ohio EPA Regulation 3745-18-63, Montgomery County Emission Limits, effective 11/01/84.

'Condition of permit.

Estimated usage listed on permit applications is $745 \mathrm{lbs} / \mathrm{yr}$. Actual emissions are much lower.

ePermit lists a 6000-gallon gasoline tank and a 4000-gallon diesel fuel tank.

fOhio EPA Regulation 3745-19-03(D), Open burning in restricted areas, effective 12/20/88. 
Gasoline Dispensing Facility. This facility includes a single, 6000-gallon, above-ground gasoline tank, and a single, 4000-gallon, above ground diesel fuel tank. Only one vehicle is refueled at a time.

\subsection{Nonradiological Releases to Surface Water}

The Mound Plant's nonradiological constituents in wastewater are regulated by the Clean Water Act (CWA) which is administered by the Ohio EPA through the issuance of an National Pollutant Discharge Elimination System (NPDES) permit. The permit identifies the constituents in the discharge, defines limits, and sets the requirements for compliance monitoring. Mound's current permit was issued in October of 1992, and will remain valid through March of 1997. In 1993, 1574 samples were collected for analysis of NPDES parameters.

\subsubsection{NPDES Monitoring Requirements}

The Mound NPDES permit requires scheduled collection and analysis at four onsite wastewater stream locations (called outfalls) that eventually discharge to the Great Miami River. These outfalls are 5601; 5602, 5603, and 5002. The permit also places flow-weighted effluent limitations on the combined discharges of Outfalls 5601 and 5602. This is known as the calculated Outfall 5001. Additional sampling is required by the permit at four offsite locations known as Outfall 5604, and Locations 5801, 5901, and 5902. All of the NPDES sampling outfalls and locations are shown on Figure 2.3. The parameters for analysis, sampling frequency, and other NPDES permit specifications are shown in Table 2.6.

Flow meters with flow totalizers and flow-proportional samplers are installed on Mound's outfalls. Mound uses flow-proportional sampling systems at Outfalls 5002, 5601, and 5602 because the discharge rates are variable at these locations. The discharge rate at Outfall 5603, an electroplating facility, is relatively constant, therefore, a time-proportional composite sample is collected from this location. A volume of $50 \mathrm{~mL}$ is automatically composited per sampling event.

Refrigerated automatic composite samplers are operational at Outfalls 5601, 5602, 5603, and 5002. Temperature is maintained between $1^{\circ} \mathrm{C}$ and $4^{\circ} \mathrm{C}$. In addition to automatic sampling, grab samples may be taken for selected parameters at all outfalls. Samples are either collected directly into the sample bottles or composited into larger bottles.

The discharge flow rates are measured at Outfalls 5002 and 5602 using a $90^{\circ}$ V-notch weir. A mechanical float is used to sense the level of water flowing over the weir. Outfall 5601 employs a 10in. Parshall flume and a Drexelbrook capacitance sensor to measure the discharge flow rate. The flow meters are calibrated to measure flow within $\pm 10 \%$ of the maximum flow rate that the meter is capable of measuring.

Outfall 5604 as well as Locations 5801,5901 , and 5902 are grab sampled; no automatic sampling systems are in place at these locations. 


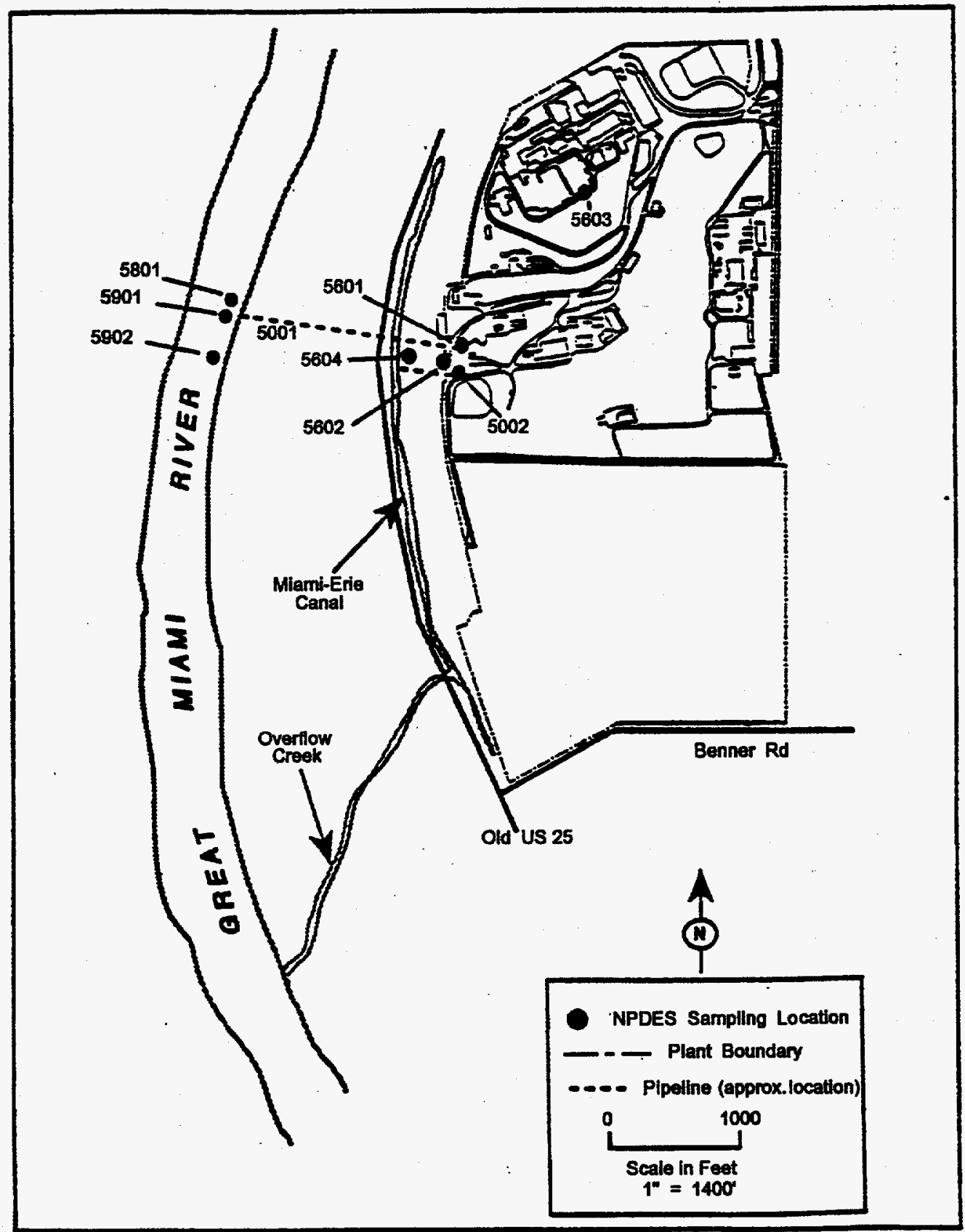

Figure 2-3. NPDES sampling locations 
Table 2-6. NPDES permit specifications

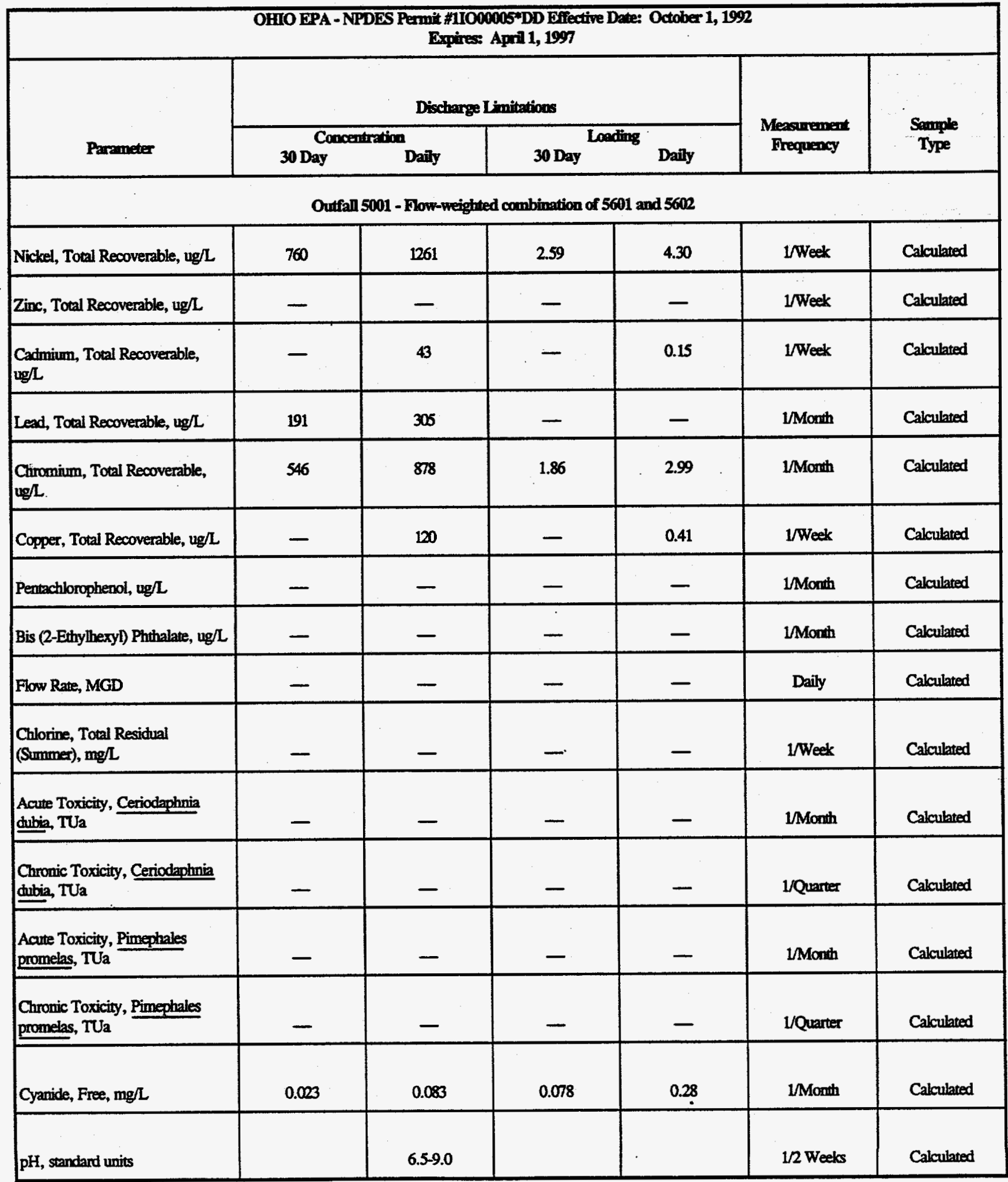


Table 2-6. (Con'd.)

\begin{tabular}{|c|c|c|c|c|c|c|}
\hline \multicolumn{7}{|c|}{$\begin{array}{l}\text { OHIO EPA - NPDES Permit \#11OOCOCF*DD Efiective Date: October 1, } 1992 \\
\text { Expires: April 1, } 1997\end{array}$} \\
\hline \multirow[b]{2}{*}{ Paramster } & \multicolumn{4}{|c|}{ Discharge Limitations } & \multirow{2}{*}{$\begin{array}{l}\text { Mesurinat } \\
\text { Frequany }\end{array}$} & \multirow{2}{*}{$\begin{array}{l}\text { Sample } \\
\text { Type }\end{array}$} \\
\hline & $30 \mathrm{Day}$ & Daily & 30 Day & Daily & & \\
\hline \multicolumn{7}{|c|}{ Outfall 5002 - Retention Basin discharge } \\
\hline $\begin{array}{l}\text { Residue, Total Nonfilterable, } \\
\text { mglL }\end{array}$ & $\mathbf{3 0}$ & 45 & - & - & 1Week & $24 \mathrm{Hr}$. Comp. (a) \\
\hline Flow Rae, MGD & - & - & - & - & Daily & 24 Hr. Estimated \\
\hline pH, standand units & & 6.5-9.0 & & & 1/Week & Grab \\
\hline
\end{tabular}


Table 2-6. (Con'd.)

\begin{tabular}{|c|c|c|c|c|c|c|}
\hline \multirow[b]{3}{*}{ Parameter } & HIO EPA & $\begin{array}{l}\text { Permit \# } \\
\text { Exp }\end{array}$ & $\begin{array}{l}\text { DDEfied } \\
1,1997\end{array}$ & October & \multirow{3}{*}{$\begin{array}{l}\text { Measurement } \\
\text { Frequency }\end{array}$} & \multirow{3}{*}{$\begin{array}{l}\text { Sample } \\
\text { Type }\end{array}$} \\
\hline & \multicolumn{4}{|c|}{ Discharge Limitations } & & \\
\hline & 30 Day & Daily & $30 \mathrm{Day}$ & Daily & & \\
\hline \multicolumn{7}{|c|}{ Outal 5601-Treatment Plant discharge } \\
\hline $\begin{array}{l}\text { Resictue, Total Nonfilterable, } \\
\text { mgl }\end{array}$ & 15 & 30 & 6.8 & 13.6 & 2Week & 24 Hr. Comp. (a) \\
\hline Oil and Grease, Total, mg/L & - & - & - & - & 1/Quanter & Grab \\
\hline Nitrogen, Ammania (NH3), mg/L & - & - & - & 一 & 1/2 Weeks & $24 \mathrm{Hr}$. Camp. \\
\hline Nickel, Towal Recoverable, ug/L & 一 & 一 & 一 & - & 1Morth & $24 \mathrm{Hr}$. Comp. \\
\hline Zine, Tonl Recoverable, ug/L & - & - & - & 一 & 1/Monh & $24 \mathrm{Hr}$. Canp. \\
\hline $\begin{array}{l}\text { Cadmium, Total Recoverable, } \\
\text { ug/L }\end{array}$ & - & - & 一 & 一 & 1Month & 24 Hr. Comp. \\
\hline Lead, Toal Recoverable, ug/L & 一 & - & - & - & 1Monin & 24 Hr. Comp. \\
\hline $\begin{array}{l}\text { Chromium, Total Recoverable, } \\
\text { ugl }\end{array}$ & - & - & - & - & 1/Month & $24 \mathrm{Hr}$. Comp. \\
\hline Copper, Total Recoverable, ug $/ \mathrm{L}$ & - & 一 & - & 一 & 1Manth & 24 Hr. Comp. \\
\hline $\begin{array}{l}\text { Feal Coliform (Summer only), } \\
\# / 100 \mathrm{~mL}\end{array}$ & 1000 & $\mathbf{2 0 0 0}$ & - & - & 1/Week & Grab \\
\hline E. Coli (Summer only), $\# / 100 \mathrm{~mL}$ & 一 & - & - & - & 1Manh & Grab \\
\hline Flow Rate, MGD & - & - & 一 & - & Daily & 24 Hr. Total \\
\hline $\begin{array}{l}\text { Chlorine, Towal Resictual (Surmmer } \\
\text { onty), mg/L }\end{array}$ & - & 0.5 & - & 0.23 & Daily(b) & Grab \\
\hline Merary, Toenl, ug/L & - & $一$ & - & - & 2ryear & $24 \mathrm{Hr}$. Comp. \\
\hline $\begin{array}{l}\text { Biochemical Oxygen Demand, } \\
\text { Carbomacous }\end{array}$ & 10 & 15 & 4.5 & 6.8 & $2 N$ Wek & 24 Hr. Comp. \\
\hline pH, standard units & & $6.5-9.0$ & & & Daily & Grab \\
\hline
\end{tabular}


Table 2-6. (Con'd.)

\begin{tabular}{|c|c|c|c|c|c|c|}
\hline \multicolumn{7}{|c|}{ 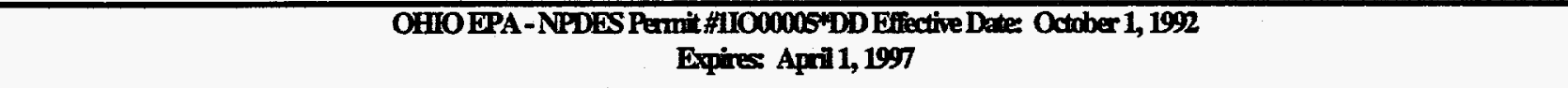 } \\
\hline \multirow[b]{2}{*}{ Parameter } & \multicolumn{4}{|c|}{ Discharge Limintions } & \multirow[b]{2}{*}{$\begin{array}{l}\text { Measurement } \\
\text { Frequency }\end{array}$} & \multirow[b]{2}{*}{$\begin{array}{l}\text { Sampe } \\
\text { Type }\end{array}$} \\
\hline & $\begin{array}{r}\text { Co } \\
\text { 30 Day }\end{array}$ & Daily & $30 \mathrm{Day}$ & Daily & & \\
\hline \multicolumn{7}{|c|}{ Ouffall 560 -Sampling Strtion } \\
\hline Cemical Oxygen Demand, mg/L & - & - & - & - & WWeak & 24Hr. Comp. \\
\hline $\begin{array}{l}\text { Reside, Total Nonfilterable, } \\
\text { mgl }\end{array}$ & 30 & 45 & 44.3 & 66.4 & 1/Wed & 24Hr. Comp. \\
\hline Oi and Grease, Total, mg/L & - & 10 & - & 14.8 & 1Manh & $\mathrm{Gmb}$ \\
\hline Fow Rat, MGD & - & - & - & - & Daily & $24 \mathrm{Hr}$. Total \\
\hline $\mathrm{pH}$, standard units & & 6.59 .0 & & & 1Weak & Grab \\
\hline
\end{tabular}


Table 2-6. (Con'd.)

\begin{tabular}{|c|c|c|c|c|c|c|}
\hline \multicolumn{7}{|c|}{$\begin{array}{l}\text { OHIO EPA - NPDES Permit "11000005*DD Effective Date: October 1, } 1992 \\
\text { Expires: April 1, } 1997\end{array}$} \\
\hline \multirow[b]{2}{*}{ Parameter } & \multicolumn{4}{|c|}{ Discharge Limitations } & \multirow[b]{2}{*}{$\begin{array}{l}\text { Measurement } \\
\text { Frequency }\end{array}$} & \multirow[b]{2}{*}{$\begin{array}{l}\text { Sample } \\
\text { Type }\end{array}$} \\
\hline & $\begin{array}{r}\text { Cor } \\
30 \text { Day }\end{array}$ & Daily & 30 Day & Daily & & \\
\hline \multicolumn{7}{|c|}{ Outfall 5603 - Electroplating Facility } \\
\hline Flow Rate, GPD & - & - & $一$ & 一 & 2Month & $24 \mathrm{Hr}$. Total Est. \\
\hline Cyanide, Toml, mg/L & 0.65 & 1.0 & 0.015 & 0.023 & 2/Month & Grab \\
\hline Cadmium, Total, ug/L & - & 100 & - & 0.0023 & 2/Month & 24 Hr. Comp. \\
\hline Chromium, Total, ug/L & - & 500 & - & 0.011 & 2/Month & 24 Hr. Comp. \\
\hline Copper, Total, ug/L & 一 & 500 & - & 0.011 & 2/Month & 24 Hr. Comp. \\
\hline Nickel, Total, ug/L & - & 500 & 一 & 0.011 & 2/Month & 24 Hr. Comp. \\
\hline Zinc, Total, ug/L & 一 & - & - & - & 2Month & $24 \mathrm{Hr}$. Comp. \\
\hline Total Toxic Organics, ug/L & - & $2130(\mathrm{c})$ & - & 0.048 & 1/Quarter & $\begin{array}{l}\text { Grab \&- or 24-hr. } \\
\text { Composite }\end{array}$ \\
\hline $\mathrm{pH}$, standard units & & $6.5-9.0$ & & & $1 / 2$ Weeks & Grab \\
\hline
\end{tabular}


Table 2-6. (Con'd.)

\begin{tabular}{|c|c|c|c|c|c|c|}
\hline \multicolumn{7}{|c|}{$\begin{array}{l}\text { OHIO EPA - NPDES Permit \#1100B005*DD Eflective Dater October 1, } 1992 \\
\text { Expires: Apri 1, } 1997\end{array}$} \\
\hline \multirow[b]{2}{*}{ Parameter } & \multicolumn{4}{|c|}{ Discharge Limitations } & \multirow[b]{2}{*}{$\begin{array}{l}\text { Measurencit } \\
\text { Frequengy }\end{array}$} & \multirow[b]{2}{*}{$\begin{array}{l}\text { Sample } \\
\text { Type }\end{array}$} \\
\hline & Co & Daily & $30 \mathrm{Day}$ & Daily & & \\
\hline \multicolumn{7}{|c|}{ Outell 5604-Minisburg Abendoned Well No. 2} \\
\hline Fow Rate, MGD & - & 一 & 一 & - & (d) & 24-Hr. Estimate \\
\hline $\mathrm{pH}$, standard units & & $6.5-9.0$ & & & (d) & Grab \\
\hline
\end{tabular}


Table 2-6. (Con'd.)

\begin{tabular}{|c|c|c|c|c|c|c|}
\hline \multicolumn{7}{|c|}{$\begin{array}{l}\text { OHIO EPA -NPDES Permit \#11000005 DD Effective Date: October 1, } 1992 \\
\text { Expires: April 1, } 1997\end{array}$} \\
\hline \multirow[b]{2}{*}{ Paramiter } & \multicolumn{4}{|c|}{ Discherge Limitations } & \multirow{2}{*}{$\begin{array}{l}\text { Measirinent } \\
\text { Frequency }\end{array}$} & \multirow[b]{2}{*}{$\begin{array}{c}\text { Sample } \\
\text { Type }\end{array}$} \\
\hline & 30 Day & Daily & $30 \mathrm{Day}$ & Daily & & \\
\hline \multicolumn{7}{|c|}{ Outfal 5801 - Great Miami River, upstrean of discharge } \\
\hline $\begin{array}{l}\text { 48-Hr. Acte Toxicity } \\
\text { Ceriodaphnia dubia, \% affected }\end{array}$ & - & 一 & - & - & 1/Monh & Composite \\
\hline $\begin{array}{l}\text { 96-Hr. Acute Toxicity Pimephales } \\
\text { promelas, \% affected }\end{array}$ & - & - & - & - & 1/Manh & Composite \\
\hline
\end{tabular}


Table 2-6. (Con'd.)

\begin{tabular}{|c|c|c|c|c|c|c|}
\hline \multicolumn{7}{|c|}{$\begin{array}{l}\text { OHIO EPA - NRDES Permit "\#LOOC005*DD Effective Date: October 1, } 1992 \\
\text { Expires: April 1, } 1997\end{array}$} \\
\hline \multirow[b]{2}{*}{ Parameter } & \multicolumn{4}{|c|}{ Discharge Linitations } & \multirow{2}{*}{$\begin{array}{l}\text { Meaniemat } \\
\text { Prequency }\end{array}$} & \multirow{2}{*}{$=$ Sanpe } \\
\hline & 30 Day & Daily & $30 \mathrm{Day}$ & Daily & & \\
\hline \multicolumn{7}{|c|}{ Outall 5901 - Great Miami River, in the mixing zone } \\
\hline $\begin{array}{l}\text { 48-Hr. Aare Toxicity } \\
\text { Ceriodaphnia dubia, \% affected }\end{array}$ & 一 & 一 & - & - & 1/Morth & Composite \\
\hline $\begin{array}{l}\text { 96-Hr. Acure Toxicity Pimephales } \\
\text { promelas, \% affected }\end{array}$ & - & - & - & - & 1/Manth. & Composite \\
\hline
\end{tabular}


Table 2-6. (Con'd.)

\begin{tabular}{|c|c|c|c|c|c|c|}
\hline \multicolumn{7}{|c|}{$\begin{array}{l}\text { OHIO EPA - NPDES Permil HIIOOC005*DD Effective Date: October 1, } 1992 \\
\text { Expires: April 1, } 1997\end{array}$} \\
\hline \multirow[b]{2}{*}{ Parancter } & \multicolumn{4}{|c|}{ Discharge Limizations } & \multirow{2}{*}{$\begin{array}{l}\text { Measurement } \\
\text { Frequency }\end{array}$} & \multirow{2}{*}{ Sample } \\
\hline & $\begin{array}{l}\text { Co } \\
\text { 30 Day }\end{array}$ & Daily & 30 Day & Daily & & \\
\hline \multicolumn{7}{|c|}{ Outell 5902 - Great Miami River, beyoud the mixing zone } \\
\hline $\begin{array}{l}\text { 7-Day Chronic Toxicity } \\
\text { Ceriodaphnia dubia, \% affected }\end{array}$ & - & - & - & - & 1/Quarter & Composite \\
\hline $\begin{array}{l}\text { 7-Day Chronic Toxicity } \\
\text { Pimephales promelas, \% affected }\end{array}$ & - & - & - & - & 1/Quarter & Composite \\
\hline
\end{tabular}

Notes for Table 2-6:

$\mathrm{TU} \mathbf{a}=$ toxicity units

Summer = May 1 through October 31

(a) Comp. $=$ composite

(b) Sampling is not required on days when facility is not normally staffed.

(c) Guideline-based limitations-not an authorization to discharge.

(d) Monitoring requirements apply when well is purged. 


\subsubsection{NPDES Sampling Locations and Descriptions}

Outfall 5601. Outfall 5601 contains the effluent from Mound's sanitary sewage treatment plant. Flowproportional, 24-hour composite samples and periodic grab samples are collected at this outfall. NPDES permit requirements for this location focus on bacteria and heavy metals. Though not a condition of the permit, Mound also analyzes the effluent quarterly for total toxic organics (TTOs).

Outfall 5602. Outfall 5602 includes storm water runoff, single-pass cooling water, cooling tower blowdown, zeolite softener backwash, and effluent from the radioactive waste disposal facility. Flowproportional, 24-hour composite samples and periodic grab samples are collected at this outfall. NPDES permit requirements for this location are more restrictive: chemical oxygen demand, suspended solids, and oil and grease content are of concern. Though not a condition of the permit, Mound also analyzes the effluent quarterly for TTOs.

Outfall 5603. Outfall 5603 is associated with an electroplating facility operated onsite. Timeproportional composite samples and periodic grab samples are collected at this outfall. Because the effluent is associated with a plating shop, the parameters of concern are heavy metals and cyanide. The NPDES permit requires quarterly TTO sampling.

Outfall 5002. Outfall 5002 contains softener backwash and most of the Plant's storm water runoff. Flow-proportional, 24-hour composite samples and periodic grab samples are collected at this outfall. NPDES permit requirements for this location focus on bacteria and heavy metals. Though not a condition of the permit, Mound also analyzes the effluent quarterly for TTOs.

Calculated Outfall 5001. Outfall 5001 represents the combined effluents of 5601 and 5602 . These discharges are combined and released to the Great Miami River via a closed pipe. Since sampling the pipe is not practical, Mound's NPDES permit imposes limits for this outfall based on flow-weighted concentration calculations. Specifically, the concentrations of materials present in Outfalls 5601 and 5602 are used, along with their respective flow rates, to estimate concentrations in the effluent discharged through the pipe.

Outfall 5604. Outfall 5604 is an abandoned well located west of the plant site. In the past, Mound has purged the well, known as Miamisburg Abandoned Well No. 2, to lower tritium concentrations. The purged water was then directed through a closed pipe to the Great Miami River. When this activity is performed, Mound's NPDES permit requires that the flow rate and $\mathrm{pH}$ be recorded. The well was most recently pumped in 1991 .

Locations 5801, 5901, and 5902. A new requirement of Mound's NPDES permit involves toxicity testing of water samples taken from the Great Miami River. The permit mandates that monthly (for acute toxicity testing) and quarterly (for chronic toxicity testing) samples be collected from specific river locations and plant effluents. The water samples are then evalauted using water fleas (Ceriodaphnia dubia) and fathead minnows (Pimephales promelas). 


\subsubsection{Procedures for Sample Collection and Analysis}

Sampling procedures for each outfall, which vary from the use of a dipper for grab samples to the collection of samples from an automated composite sampler, and the associated analytical procedures are documented in Technical Manual MD-80030, Environmental Analytical Procedures. A brief summary of the specific procedures related to nonradiological liquid effluent follows; all are incorporated by reference into this Plan. It should be noted that certain parameter analyses and river sample collections are contracted to outside laboratories who must meet EPA and Mound QA requirements.

Operation 8218 , Nonradioactive Parameters in Effluent Water, references analytical procedures that have been approved by the EPA for measurement of NPDES constituents. Most of the procedures are found in the Code of Federal Regulations (40 CFR 136). Although there are multiple methods for each parameter, only the methods used by Mound are referenced here. Since there are approximately eighty procedures, they are not summarized individually.

Operation 9081, Routine Collection of Effluent Water Samples for Radioactive and NPDES Monitoring, describes the sampling location, frequency, and equipment used to collect samples from the Mound Plant's liquid effluents for both radionuclide and nonradionuclide constituents. Flowproportional composite samples are collected each workday morning from Outfalls 5601, 5602, and 5002. The sampling technician documents the flow metering data from each of the monitoring stations. Additional grab samples are collected at frequencies specified by the NPDES permit (Table 2-6). Grab and time-proportional composite samples are collected on a monthly basis from Outfall 5603.

\subsection{Data Management and Quality Assurance}

\subsubsection{Data Logbooks}

Results of sample analyses are maintained in controlled logbooks and Lotus spreadsheets. The following logbooks are used to maintain radiological and nonradiological water effluent data. All are incorporated by reference into this Plan.

Mound Control Number

6177A and 6177B

7850

6250

6445

$6943 \mathrm{~A}$

6943F
Title

Sample Receipt Log

Tritium Analysis Onsite and Offsite Water Record

Gross Alpha Analysis Onsite Water Record

Water Analysis Data NPDES

Uranium Water Analysis Record Onsite and Offsite

Plutonium Water Analysis Record Onsite and Offsite 


\subsubsection{Quality Assurance}

To some extent, the environmental analytical procedures of MD- 80030 are quality control procedures. Another key element of effluent monitoring QA, however, is chain of custody. The following operations define Mound's approach to chain of custody for effluent samples. The procedures listed below are incorporated by reference into this Plan.

Operation Number 9284, Tritium Stack Bubbler Sample Chain of Custody Procedure. Samples from the tritium stack bubblers are collected by Health Physics technicians who, in turn, transfer the vials to environmental technicians for laboratory analysis and evaluation. Operation 9284 establishes the transfer procedure to ensure sample integrity, and to provide standardized reporting formats for auditable records.

Operation Number 9286, Particulate Stack Sample Chain of Custody Procedure. The particulate (plutonium and uranium) stack samples are collected by Health Physics technicians, counted twice in seven days by health physics counting lab technicians, retained by health physics until all the samples for the month are collected, and then transferred to the environmental technicians for monthly composite analysis and evaluation. This procedure documents the transfer and storage procedures to ensure sample integrity, and to provide standardized reporting formats for auditable records.

Mound Technical Manuals. In addition to the Environmental Analytical Procedures (MD-80030) for chain of custody and lab analyses, QA/QC requirements are contained in the Quality Plan for Bioassay and Environmental Monitoring (MD-10321), and the Mound Environmental Section Quality Control Manual (MD-10176). These manuals describe participation in external QA programs, statistical measures of accuracy, precision, and confidence; and procedures for determining the types of quality assurance programs necessary for various environmental measurements.

The development of more extensive quality control procedures including equipment redundancy, critical parts inventory, preventative maintenance, calibration, and operator training is part of the radionuclide stack monitoring upgrade projects (Section 2.2.4). 


\subsection{METEOROLOGICAL MONITORING}

Mound's meteorological monitoring program provides information on weather conditions that can be used to forecast atmospheric dispersion following planned or unplanned releases of airborne material. Performance criteria and documentation requirements for meteorological monitoring programs at DOE facilities are detailed in the Regulatory Guide (DOE, 1991a). Additional guidance applicable to the Plant has been issued by the U.S. Environmental Protection Agency (EPA, 1987).

\subsection{Rationale}

Pursuant to the Regulatory Guide, the principal uses of meteorological data at DOE sites are to assess the:

- consequences of routine atmospheric releases,

- consequences of unplanned atmospheric releases, and the

- potential consequences of atmospheric releases from projected or modified facilities.

Mound has an extensive network of hardware and software designed to meet these goals. Specific information on key elements of the monitoring program follows below.

\subsection{Instrumentation}

Primary tower. The primary tower is located on a topographic high referred to as the Main Hill. The elevation of the tower base is approximately $282 \mathrm{~m}(920 \mathrm{ft})$ above sea level. Instruments located on this tower measure wind speed, wind direction, and temperature at the 50-m (164-ft) level above the base. This elevation is comparable to the height at which materials are released into the atmosphere from the principal stacks on the Main Hill. At the 1-m (3-ft) level, temperature and dew point are measured. The tower is also equipped with a tipping bucket rain gauge.

Secondary tower. A second tower is located in a topographic low below the Main Hill. The elevation of the tower base is approximately $230 \mathrm{~m} \mathrm{(750} \mathrm{ft)} \mathrm{above} \mathrm{sea} \mathrm{level.} \mathrm{Wind} \mathrm{speed,} \mathrm{wind} \mathrm{direction,} \mathrm{and}$ temperature are measured at the $10-\mathrm{m}(33-\mathrm{ft})$ level. Operation of this tower ensures that Mound can adequately characterize dispersion during ground-level and near-ground-level releases. Data from this tower are also used to evaluate transport and diffusion during conditions unfavorable to dispersion (e.g., calm winds at ground level and/or an inversion).

Atmospheric stability measurements. At Mound, atmospheric stability determinations are made by estimating the amount of atmospheric turbulence in the lateral wind direction. This approach is the socalled "sigma a" $\left(\sigma_{\mathrm{A}}\right)$ approach, where $\sigma_{\mathrm{A}}$ represents the standard deviation of the fluctuation in the horizontal wind field. Sigma a values are determined for Mound using a bi-directional wind vane. Atmospheric stability assignments are then made for a given time period based on the $\sigma_{\mathrm{A}}$ value during that period. Large $\sigma_{\mathrm{A}}$ values indicate turbulent conditions (favorable for dispersion); small $\sigma_{\mathrm{A}}$ values indicate stable conditions (unfavorable for dispersion). 


\subsection{Data Management}

A Handar computer receives and summarizes signals from the sensors on the towers. A DEC computer then compiles the Handar data and generates records of wind speed, wind direction, wind stability, temperature, dew point, percentage relative humidity, and rainfall. Key data are archived permanently in a data base of 15 -minute averages. The data are also available as hourly averages for use in dispersion calculations. Mound's goal for recovery of data used to estimate annual dispersion patterns is $100 \%$. Recent calendar year recovery rates for the data have ranged from 91.1 to 99.9 percent.

\subsection{Routine Releases}

To estimate dispersion of airborne materials released throughout the year, the principal information needed is the frequency of specific combinations of wind speed, wind direction, and atmospheric stability. These data are archived for each calendar year in the form of a joint frequency distribution (JFD). The JFD is then used to estimate annual average concentrations as a function of distance and compass sector relative to Mound.

For atmospheric releases of radioactivity, Mound uses the computer codes CAP-88 (Moore et al., 1979), CAP88-PC (EPA, 1992), and XOQDOQ (Sagendorf et al., 1982) to generate estimates of radionuclide concentrations in the offsite environment. In each case, the estimates are based on a straight-line Gaussian plume model.

Routine releases of nonradiological constituents to the atmosphere are limited to the materials shown in Table 2-5. Process knowledge, rather than a modeled approach, is typically used to estimate annual release rates. Further, because of the small volumes and masses released, modelled estimates of groundlevel concentrations are rarely needed.

\subsection{Emergency Response Capabilities}

An important capability for the Mound Plant is the ability to respond to unplanned releases of radioactive and/or chemical materials to the atmosphere. This capability could prove vital during an inadvertent release of materials from Mound or a nearby industry.

\subsubsection{Atmospheric Release Advisory Capability (ARAC)}

Primary emergency response support for Mound is maintained through its relationship with the Atmospheric Release Advisory Capability (ARAC) Group at Lawrence Livermore National Laboratory. During an unplanned release of gases or particulates to the atmosphere, source term and weather data are reviewed by the ARAC Group. The ARAC Group responds with real-time assessments of the potential consequences of the release. The ARAC Group consists of more than 30 scientists with baccalaureate and advanced degrees in such disciplines as meteorology, atmospheric science, computer science, and mathematics. 
The chief wind field and diffusion models of ARAC are MATHEW and ADPIC, respectively. MATHEW is a mass-adjusted three-dimensional wind field model; ADPIC is an atmospheric diffusion particle-in-cell model. MATHEW/ADPIC can be used to generate puffs or plumes to evaluate:

- particulate and gaseous concentrations,

- particle deposition as a function of particle size, and

- rainout for distances up to several hundred kilometers.

The onsite capabilities associated with the ARAC system make it possible to provide real-time wind speed and direction information to the Emergency Operations Center (EOC) at 15-minute intervals. It is also possible to generate plume data (Figure 3-1) for transmission to the EOC.

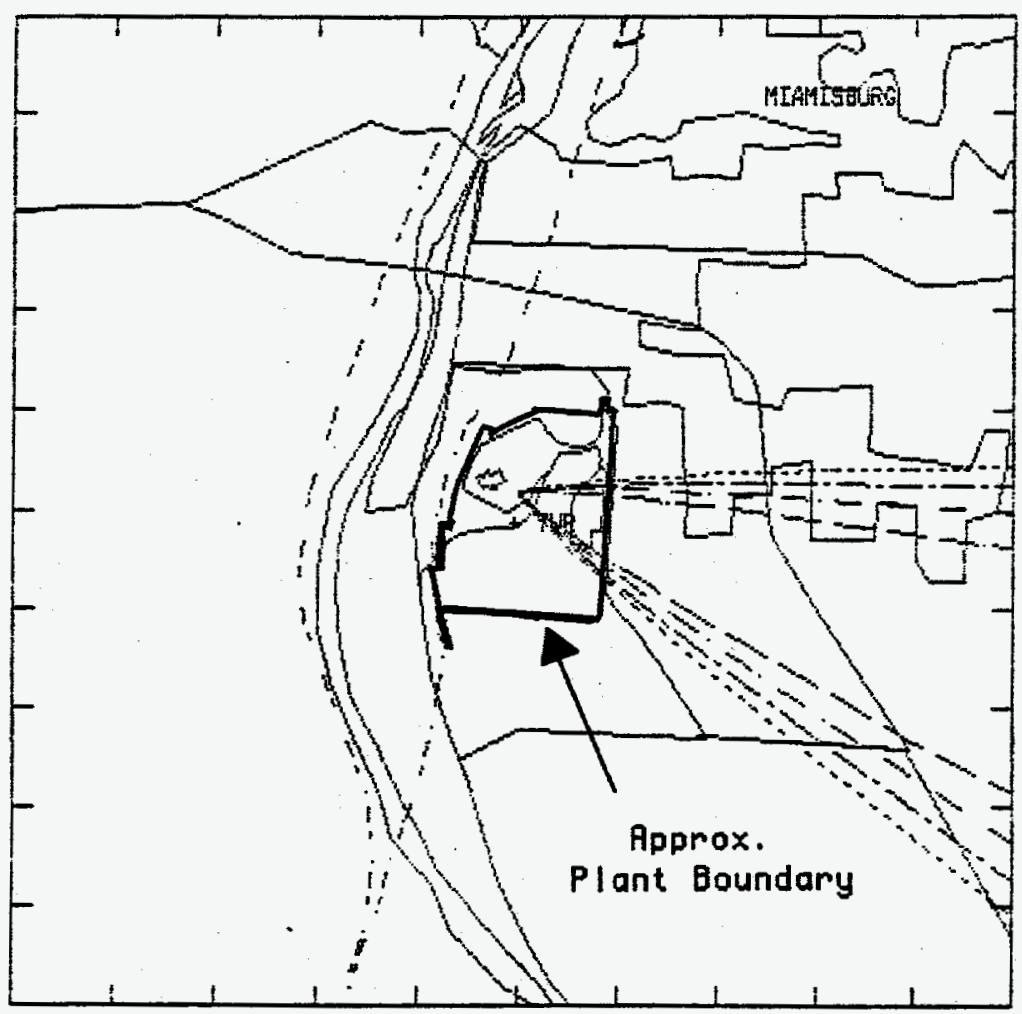

SURFACE DISFLAYS

Contour $\equiv-0 u t$ To In: Ci/M

$1 E-12 \quad 1 E-10 \quad 1 E-00 \quad 1 E-06$

Date/Time= 060ECS3 1450

Wind $=289 \mathrm{Q} 10.4 \mathrm{MFS}$

Stn Level = MOLND 12

Loostion = UTME: 0732.842

Stability=0 TMN: 4390.033

Souree $H t=00$ Meters

Sample Ht= 2 Meters

Tupe = Plume/Puff

Source $=150$ Ci/sec

Hiff Life= 2.11Ee Hour

Map Center UTME $=732.841 \mathrm{~km}$

Map Center UTMN $=4389.953 \mathrm{~km}$

Center $=0.50 \mathrm{~km}$

Figure 3-1. ARAC-generated graphics: simulated plume 


\subsubsection{CAMEO}

The ARAC system described previously would be activated during a real or simulated emergency involving the release of radioactive materials to the atmosphere. However, in the event the release involved a chemical constituent, the CAMEO system would be activated. "CAMEO"represents an-inprogress enhancement to Mound's emergency response capabilities. CAMEO includes the PC-based programs CAMEO, MARPLOT, and ALOHA. Through these programs, chemical release and reference data can be linked to onsite meteorological data to produce concentration contour maps. The site map upon which the concentration contours will be overlaid is shown in Figure 3-2.

CAMEO is designed to receive real-time data from a portable 10 -m meteorological tower. For this reason, it is a powerful assessment tool for ground-level or near-ground-level release scenarios or events. It is anticipated that CAMEO will be fully operational at Mound effective December 31, 1994.

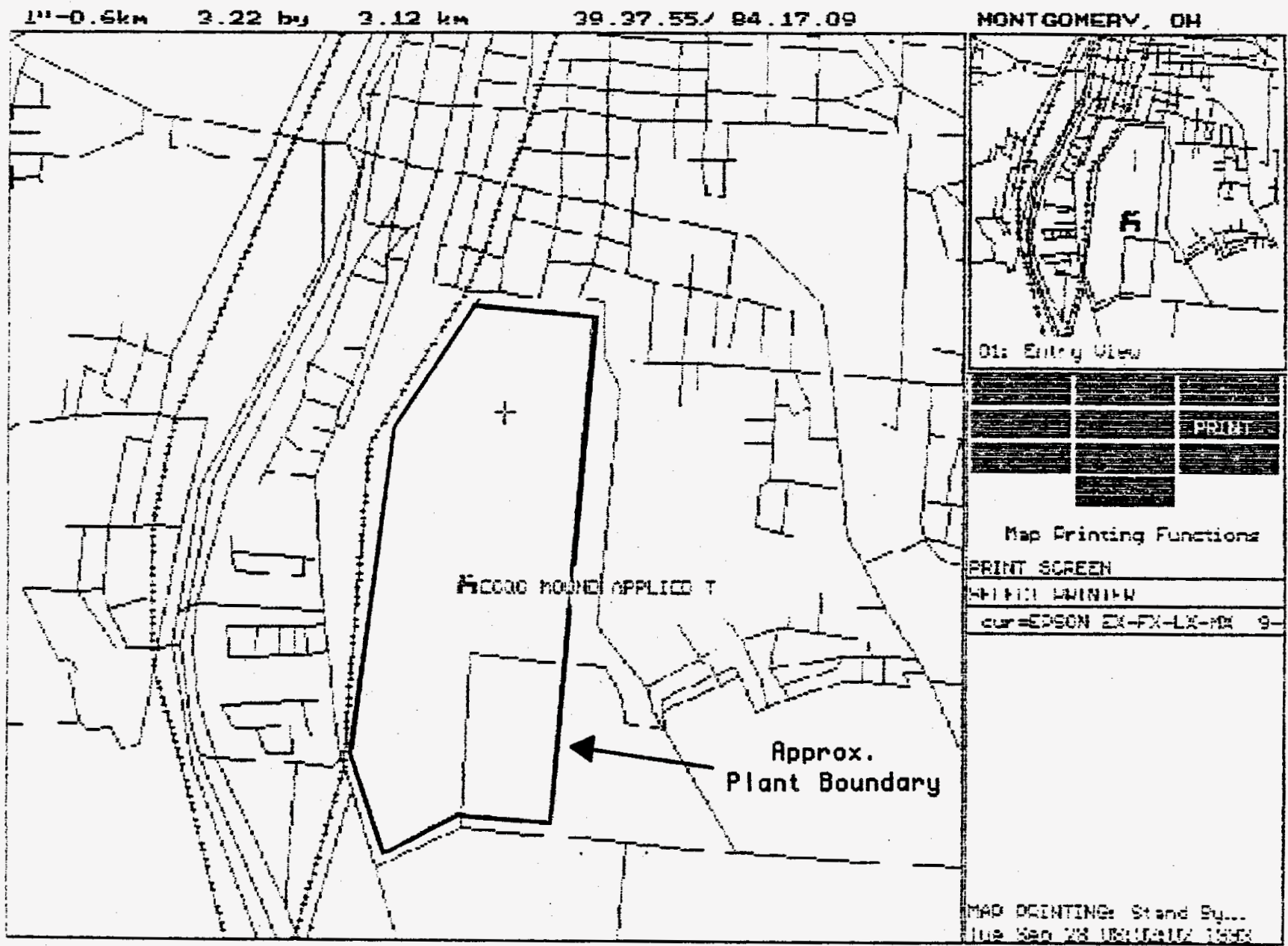

Figure 3-2. CAMEO-based site map 


\subsection{Quality Assurance Procedures and Responsibilities}

To the fullest extent possible, EG\&G Mound operates the meteorological monitoring program in compliance with the applicable quality assurance (QA) requirements of the Regulatory Guide, DOE Order 5700.6C (DOE, 1991b), and EPA standards for performance. Specific actions taken to ensure the quality of the data are described below.

\subsubsection{Instrument Calibration and Maintenance}

The primary responsibility for the quality of the data generated by Mound's meteorological monitoring program lies within the Environmental Technology Group of EG\&G Mound. The Environmental Technology Group ensures that all scheduled maintenance and calibration activities are performed for the equipment in accordance with the recommendations of the manufacturers. Replacement of calibrated tower sensors is completed once each calendar year. During those exercises, the orientation, position, and signal strength of the equipment is verified using the ARAC site system. The work is performed by personnel associated with the Bureau of Land Management, Boise, Idaho. These individuals are uniquely qualified to calibrate and evaluate the equipment. All documents associated with instrument calibration and equipment performance are retained as permanent records.

\subsubsection{Training}

It is also the responsibility of the Environmental Technology Group to ensure that onsite users of the ARAC system receive adequate training. Certified instructors from the ARAC Group of Lawrence Livermore National Laboratory conduct on-site training exercises. These exercises are completed annually as a best management practice. Certificates are issued to individuals who successfully complete the training. Documentation of the training is retained permanently.

\subsubsection{Audits}

The meteorological monitoring program at Mound is subject to external review by the Dayton and Albuquerque Offices of DOE. Programmatic information is also made available to the Regional Air Pollution Control Agency, the Ohio Environmental Protection Agency, and the U.S. Environmental Protection Agency. Additionally, the program is subject to periodic audits by the Performance Assurance Department of EG\&G Mound. Members of the Performance Assurance Department provide independent verification that necessary procedures and policies have been established and are being followed. This verification is made by monitoring staff members during the routine performance of their duties. Their actions are compared to the actions specified in applicable written procedures. Any discrepancy is noted and must be promptly resolved. Satisfactory resolution of any such discrepancy is tracked by the Performance Assurance Department. 


\subsection{ENVIRONMENTAL SURVEILLANCE}

As described in Chapter 2, operations at the Mound Plant result in the discharge of effluents to the air and the Great Miami River. To evaluate any impact these releases may have on human health and the environment, Mound collects and analyzes numerous samples each year from a variety of environmental media. The sampling programs in place for each medium are described in the following sections.

An effective environmental surveillance program requires comparisons of concentrations measured in the environment with background levels. For purposes of this report, a "background" location is defined as an area unaffected by Mound releases. Background samples for Mound are collected from areas that represent substantial distances from the Plant and/or the least prevalent downwind directions. Environmental monitoring samples, conversely, are collected from locations where impacts from Mound operations are most likely to be detected.

\subsection{Ambient Air}

\subsubsection{Program Objectives}

Mound maintains a network of ambient air surveillance stations to monitor the impact of airborne radiological emissions on the local and regional environments. Specifically, the goals of the ambient air monitoring program are to :

- document compliance with applicable federal, state, and local regulations and DOE Orders,

- quantify environmental impacts of planned and unplanned releases,

- verify proper operation of stack emission control mechanisms,

- evaluate the effectiveness of the site's efforts to reduce emissions, and to

- promote public trust by providing accurate environmental data.

\subsubsection{Operational Specifications}

Two types of samples are collected continuously at each air sampling location. A particulate air sample is collected and analyzed for plutonium-238 and plutonium-239,240. "Mass loadings" or dust concentrations are also evaluated using these samples. A second air sample, collected in a bubbler apparatus, is analyzed for tritium oxide (HTO). The sampling equipment is housed in a shelter of wooden construction. The shelters provide protection from disturbances relating to weather, tampering, or theft. Each side of these shelters, or "stations", has louvered panels to provide adequate air flow. 


\section{Siting Criteria}

Mound operates a network of 22 stations; seven onsite and 15 offsite. The locations of the stations are shown in Figures 4-1 and 4-2, respectively, for the offsite and onsite stations.

The number and placement of the offsite air sampling stations has been evaluated based on the methodology developed by Waite (1973a and 1973b). Waite's technique optimizes sampling station placement based on the population distribution and the prevailing winds. In that approach, the available sampling stations are preferentially sited in the compass sectors that are home to the largest numbers of people and/or are in the prevailing downwind directions. One exception to that rule applies. Toestablish background concentrations, one station is located in the least prevalent wind direction.

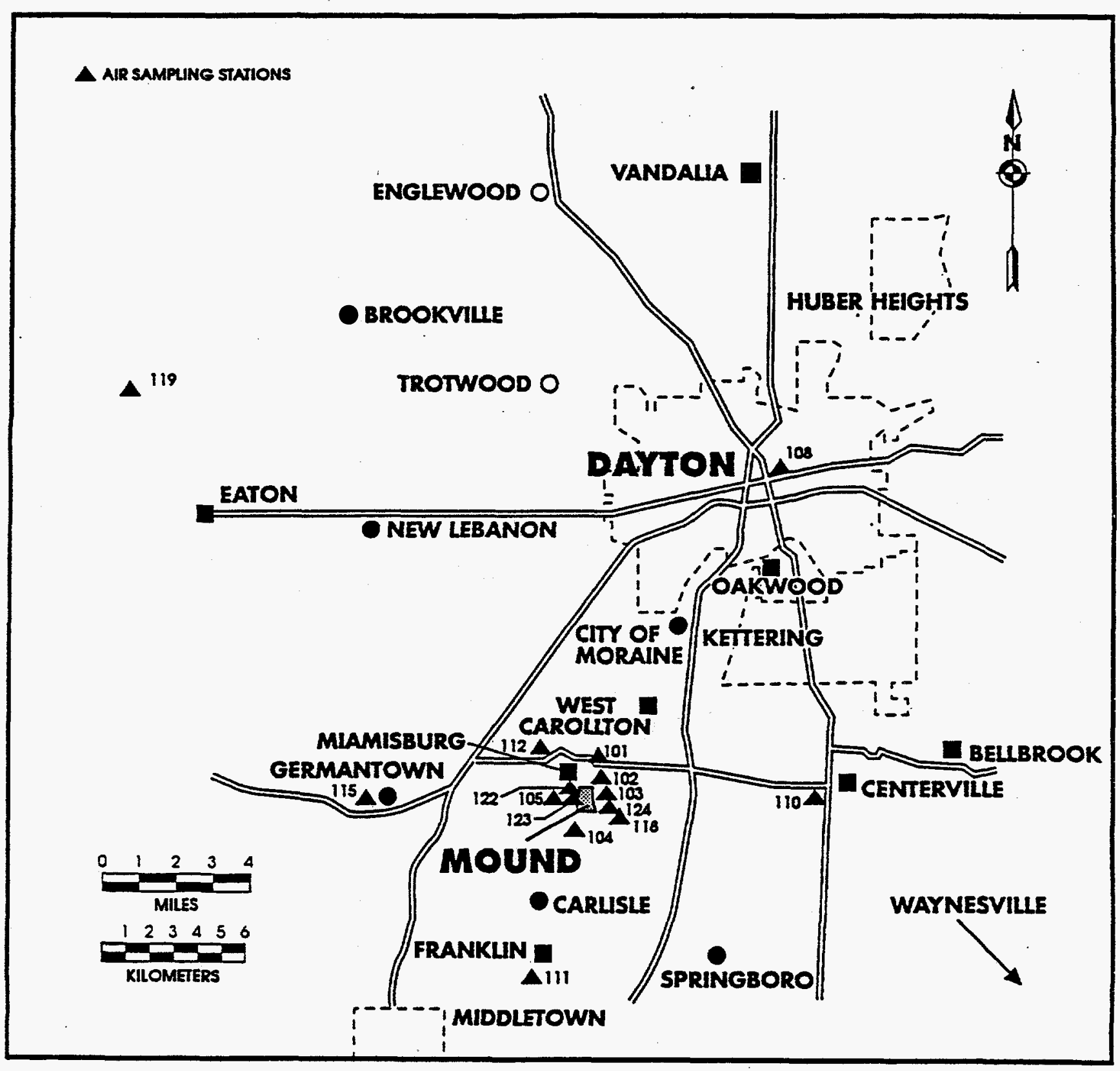

Figure 4-1. Offsite air sampling locations 


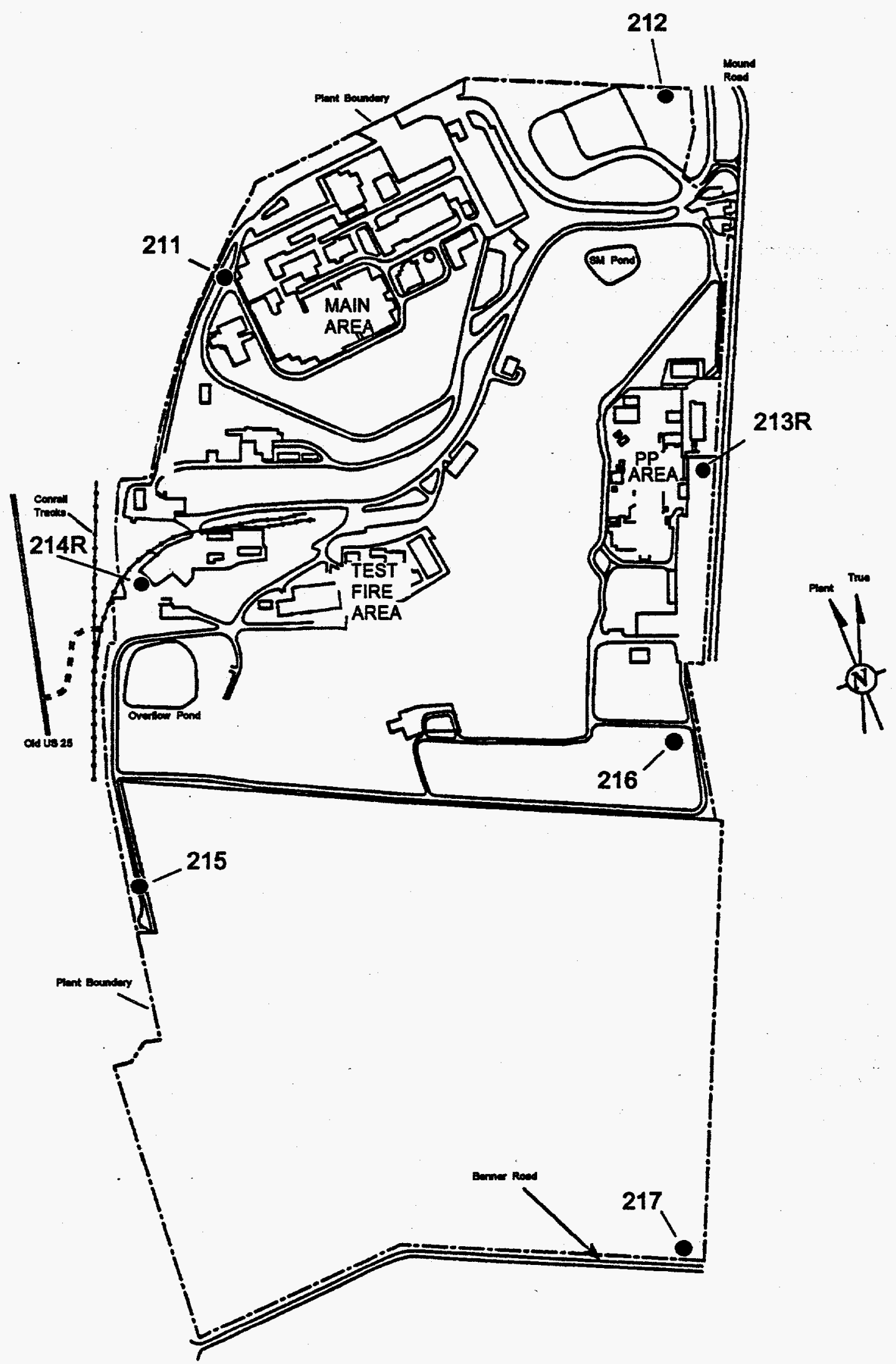

Figure 4-2. Onsite air sampling locations 
As seen in Figure 4-2, the onsite stations have been sited near the Plant perimeter to provide estimates of impacts at the site boundary or "fence line". The onsite stations were placed based on:

- their proximity to operational areas, and/or

- their proximity to decommissioning activities, and

- the prevailing wind directions for the site.

The shelters are located, to the extent feasible, in areas free from localized effects such as buildings, trees, or fugitive dust sources. Siting requirements established in the Regulatory Guide and in EPA regulations (40 CFR Part 58, Appendices A through E) are consulted during inspections of shelter locations. The guidelines are also consulted prior to shelter construction or relocation.

\section{Plutonium Sample Collection and Analysis}

Plutonium samples are collected at a height of approximately $0.7 \mathrm{~m}(2.3 \mathrm{ft})$. The use of a $0.7-\mathrm{m}$ sampling height provides Mound with a mechanism of detecting plutonium released from the Plant stacks and from the ground surface. The release of plutonium from ground surfaces (resuspension) is a potentially significant transport mechanism for the site. At the onsite stations, samples are also collected from a height of $2 \mathrm{~m}$. This approach ensures that onsite impacts from elevated, as well as ground-level, releases are fully evaluated at points where vertical concentration gradients may exist.

Sample collection. Plutonium concentrations in air are determined based on the collection of particulate matter on a ultra-pure quartz fiber filter. Air is passed across the filter at a nominal flow rate of $1.3 \times 10^{6}$ $\mathrm{cm}^{3} / \mathrm{min}(45 \mathrm{cfm})$. The filter in use at Mound removes $99.99 \%$ of the particles in the $0.4-0.06$ micron range. The removal efficiency for particles of 0.5 microns and larger is $99.999 \%$.

The filter is changed weekly and represents a sample volume of approximately $1300 \mathrm{~m}^{3}$ of air. Experience at Mound has shown this retrieval interval to be sufficiently lengthy to detect plutonium of Mound origin. This collection frequency also provides an opportunity to conduct weekly inspections of the stations. Typical lower limits of detection for this technique are on the order of $10^{-18} \mu \mathrm{Ci} / \mathrm{mL}$.

Sample analysis. Filters collected from the seven onsite stations and the three closest offsite stations (Stations 122,123 , and 124) are analyzed monthly by compositing the weekly samples. Weekly filter samples from the remaining stations are analyzed quarterly. The protocols followed to analyze the samples are documented in Mound Manual MD-80030, Environmental Analytical Procedures. The applicable operations are Operation 9180, Collection of Onsite Particulate Radionuclide Air Samples; Operation 1110, Plutonium in Air by Acid Leaching: and Operation 1112, Plutonium in Air by Acid Dissolution. The analytical procedures involve sample decomposition with heat, followed by leaching with nitric acid. The plutonium is separated by anion exchange chromatography and electrodeposited onto stainless steel slides. Alpha pulse height analysis is then performed using a silicon surface barrier detector. Operations 9180,1110 and 1112 of MD-80030 are incorporated by reference into this Plan. 


\section{Particulate Load Determinations}

The filters from the high-volume air samplers described above are also used to determine concentrations of particulates in air. These measurements verify that dust levels associated with Plant activities, such as construction and traffic, do not exceed ambient levels. The protocol followed to generate the concentration data is documented in Mound Manual MD-80030, Environmental Analytical Procedures. The applicable operation is Operation 1170, Mound Filter Processing Procedure. Given (1) the weight of the filter before and after use, and (2) the volume of air to which the filter was exposed, the average particulate-in-air concentration for that exposure period is readily determined. Operation 1170 is incorporated by reference into this Plan.

\section{Tritium (HTO) Sample Collection and Analysis}

Tritium samples are collected at heights of $1-2 \mathrm{~m}(3-6 \mathrm{ft})$. The use of this range of sampling heights is adequate to detect tritium oxide released from the Plant stacks. (Tritium is not a likely candidate for resuspension and near-ground-level samples are therefore not required.)

Sample collection. Tritium oxide (HTO) concentrations in air are determined based on the collection of tritiated water vapor in ethylene glycol. Ethylene glycol is used as the trapping agent because it is not subject to loss by evaporation and will not freeze when exposed to winter sampling conditions. Ethylene glycol removes $85-95 \%$ of the tritiated water vapor from the air.

Ambient air is passed through $200 \mathrm{~mL}$ of glycol at a nominal flow rate of $1000 \mathrm{~cm} 3 / \mathrm{min}(0.03 \mathrm{cfm})$. The glycol solution is changed weekly and represents a sample volume of approximately $10 \mathrm{~m}^{3}$ of air. Experience at Mound has shown this retrieval interval to be sufficiently lengthy to detect HTO of Mound origin. This collection frequency also provides an opportunity to conduct weekly inspections of the stations. Typical lower limits of detection for this technique are on the order of $20 \times 10^{-12} \mu \mathrm{Ci} / \mathrm{mL}$.

Sample analysis. The ethylene glycol solutions collected weekly from each of the 22 sampling stations are analyzed using a liquid scintillation counter. Offsite samples are collected for Mound by the Regional Air Pollution Control Agency. Onsite samples are collected by Mound personnel. Mound protocols followed to collect and analyze the samples are documented in Mound Manual MD-80030, Environmental Analytical Procedures. The applicable procedure is Operation 2157, Tritium Oxide Analysis in Ambient Air. In Operation 2157, two-mL aliquots of each ethylene glycol sample are added to $20 \mathrm{~mL}$ of a liquid scintillation cocktail prior to liquid scintillation analysis. The nominal counting period is 200 minutes. Operation 2157 is incorporated by reference into this Plan. 


\subsection{Surface Water and Sediment}

\subsubsection{Program Objectives}

Mound's surface water and sediment monitoring programs have been designed to meet the requirements of DOE Orders 5400.1 and 5400.5 and the Regulatory Guide. Specific program goals are to:

- detect, characterize, and report planned and unplanned releases,

- monitor overall water quality, and to

- detect, characterize, and report evidence of long-term trends.

\subsubsection{Sample Collection and Analysis}

The Great Miami River and other regional surface waters are sampled routinely by Mound for tritium, isotopes of plutonium, and isotopes of uranium. Sediment samples are also collected from these locations and analyzed for plutonium isotopes. Approximate sampling locations are shown in Figure 4-3.

Great Miami River. Six river locations are routinely sampled by Mound. The locations provide -samples that are representative of river water before and after complete mixing of Mound's effluents with the river. Tritium samples are collected and analyzed weekly; plutonium-238, plutonium-239,240, uranium-233,234, and uranium-238 samples are collected and analyzed monthly.

Regional surface waters. To detect atmospheric deposition on water, it is also necessary to sample area lakes and ponds. Seven ponds in various directions from Mound are sampled quarterly. These samples are analyzed for tritium, plutonium-238 and plutonium-239,240.

Sediments. Many plutonium solutions, including those in use at Mound, are relatively insoluble in water. Therefore, they are more likely to be found in sediment than in surface water. Additionally, because of the relatively long half-lives of key isotopes of plutonium, plutonium has the potential to accumulate in sediments over a number of years. For this reason, Mound samples river and pond sediments on a quarterly basis. These samples are then analyzed for plutonium-238 and plutonium239,240 .

Tritium analyses of surface water are performed on a weekly basis. Plutonium and uranium analyses are performed monthly. Sampling protocols have been designed to ensure that sample collection is representative of water flowing past the sampling site. The sampling and analytical procedures used to evaluate surface water samples are documented in Mound Technical Manual MD-80030, Environmental Analytical Procedures. The applicable procedures are identified in Table 4-1; all such procedures are incorporated by reference into this EMP. 


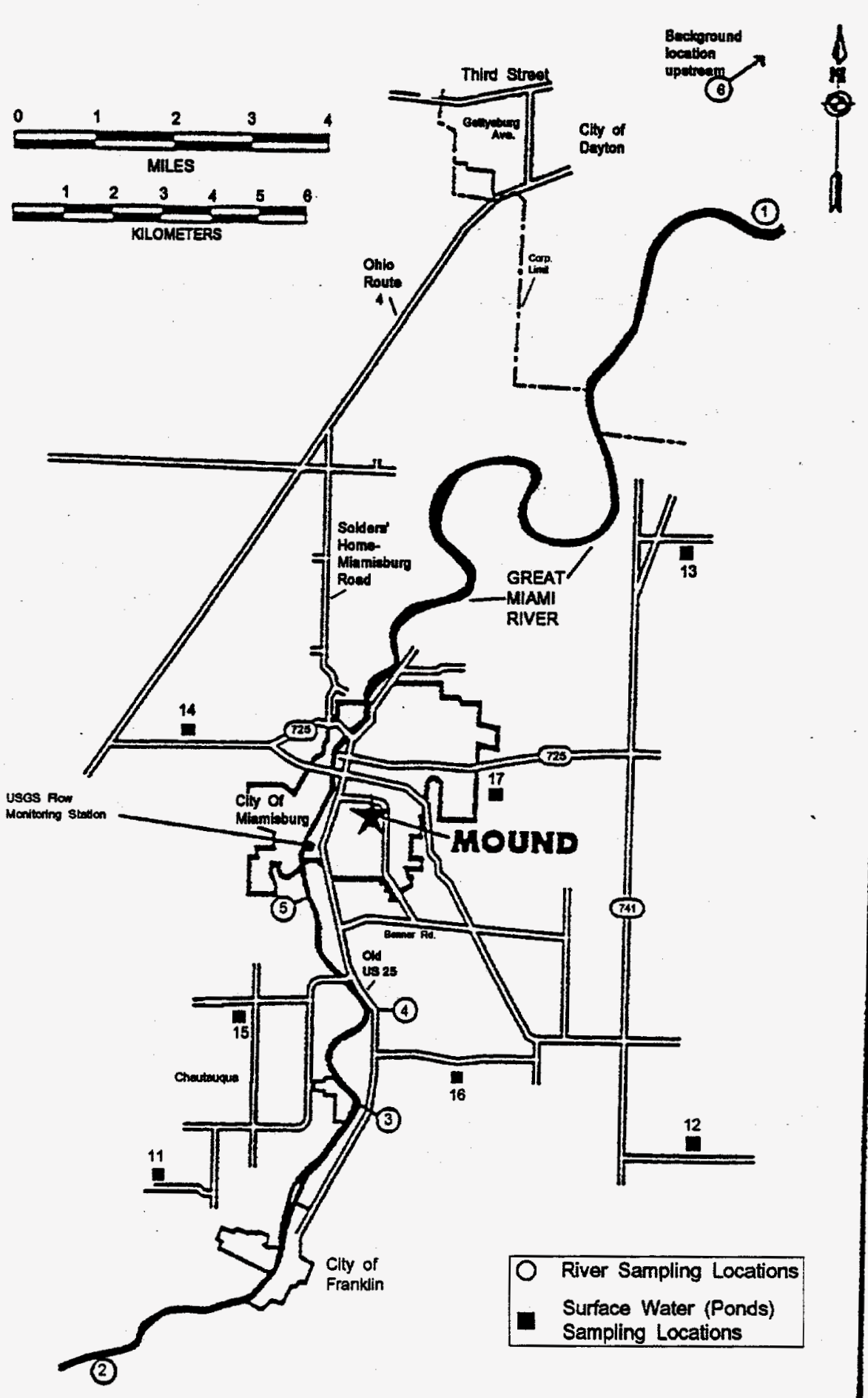

Figure 4-3. Sampling locations for river water, pond water, and sediments 
Table 4-1. Procedures for surface water and sediment sample collection and analysis*

\begin{tabular}{|c|c|}
\hline $\begin{array}{c}\text { Operation } \\
\text { No. }\end{array}$ & Title \\
\hline $\begin{array}{l}9274 \\
9275 \\
9276 \\
9277\end{array}$ & $\begin{array}{l}\text { Collection of On-site and Off-site Large Volume Water Samples } \\
\text { Collection of Large Volume Pond Samples } \\
\text { Collection of Large Volume River Samples } \\
\text { Collection of Weekly and Monthly River Grab Samples }\end{array}$ \\
\hline 1201 & Plutonium in Water by a Coprecipitation Anion Exchange Method \\
\hline 1385 & Leachable Plutonium in Soild Matrix \\
\hline 2261 & Tritium in Environmental Water Samples \\
\hline 3240 & Radiochemical Determination of Uranium Isotopes in Water \\
\hline
\end{tabular}

a All procedures are documented in Mound Technical Manual MD-80030, Environmental Analytical Procedures, and are incorporated by reference into this EMP.

\subsection{Aquatic Biota}

Biomonitoring. As indicated in Chapter 2, aquatic organisms are used as test species to evaluate any detrimental impact Mound's liquid effluents may have on the Great Miami River. The indicator species are Ceriodaphnia dubia (water flea) and Pimephales promelas (fathead minnow). As specified by Mound's National Pollutant Discharge Elimination System (NPDES) permit, chronic and acute toxicity testing of these species is performed routinely (Sample locations and frequencies are described in Section 2.5.2). Sampling and analysis for biomonitoring of the river is performed by a contract laboratory. The laboratory has been certified to perform the analyses by the Ohio EPA.

BMP Monitoring. In addition to the toxicity testing of the river, as a best management practice (BMP), Mound also collects fish samples for radioanalysis. Because the primary long-lived element in residence below the Plant's outfalls is plutonium, environmental surveillance of aquatic species focuses on plutonium-238 and plutonium-239,240. Further, since plutonium has a strong affinity for river sediments, efforts are exercised to collect bottom-dwelling fish such as carp and catfish.

Each year, attempts are made to collect at least four samples for analysis. The fish are placed on ice and returned to the environmental laboratory at Mound where each fish is filleted and weighed. Filleted samples are then ashed and subjected to the following analytical protocol of MD-80030, Environmental Analytical Procedures: Operation 9281, Plutonium in Fish and Vegetation by An Acid Leach Method. Operation 9281 of MD-80030 is incorporated by reference into this EMP. 


\subsection{Foodstuffs and Vegetation}

Various locally grown foodstuffs and vegetation are collected during their respective growing seasons. The intent of this aspect of the environmental monitoring program is to determine whether radionuclides of Mound origin are being deposited on, or otherwise accumulated by, specific indicator species. Results of the analyses are used to monitor long-term concentration and accumulation trends, and to evaluate potential doses via the ingestion exposure pathway.

The sampling locations, media, and radionuclides of interest are shown in Table 4-2. As seen in the table, tomatoes, because of their high water content, are used as an indicator of tritium uptake. Conversely, for plutonium-238, root crops are used because of their extensive contact with soil.

Table 4-2. Vegetation and foodstuffs sampling program

\begin{tabular}{|c|c|c|}
\hline Location & Media & Radionuclides \\
\hline Miamisburg, $\mathrm{OH}$ & $\begin{array}{l}\text { Grass } \\
\text { Root crops } \\
\text { Tomatoes }\end{array}$ & $\begin{array}{l}\text { Tritium, }{ }^{238} \mathrm{Pu},{ }^{239.240} \mathrm{Pu} \\
{ }^{238 \mathrm{Pu},}{ }^{239,240} \mathrm{Pu} \\
\text { Tritium }\end{array}$ \\
\hline Centerville, $\mathrm{OH}$ & $\begin{array}{l}\text { Grass } \\
\text { Root crops } \\
\text { Tomatoes }\end{array}$ & $\begin{array}{l}\text { Tritium, }{ }^{238} \mathrm{Pu},{ }^{239.240} \mathrm{Pu} \\
{ }^{238} \mathrm{Pu},{ }^{239.240} \mathrm{Pu} \\
\text { Tritium }\end{array}$ \\
\hline Bellbrook, $\mathrm{OH}$ & $\begin{array}{l}\text { Grass } \\
\text { Root crops } \\
\text { Tomatoes }\end{array}$ & $\begin{array}{l}\text { Tritium, }{ }^{238} \mathrm{Pu},{ }^{239,240} \mathrm{Pu} \\
{ }^{238} \mathrm{Pu},{ }^{239.240} \mathrm{Pu} \\
\text { Tritium }\end{array}$ \\
\hline Trotwood, OH & $\begin{array}{l}\text { Grass } \\
\text { Root crops } \\
\text { Tomatoes }\end{array}$ & $\begin{array}{l}\text { Tritium, }{ }^{238} \mathrm{Pu},{ }^{239,240} \mathrm{Pu} \\
{ }^{238} \mathrm{Pu},{ }^{239,240} \mathrm{Pu} \\
\text { Tritium }\end{array}$ \\
\hline Franklin, OH & $\begin{array}{l}\text { Grass } \\
\text { Root crops } \\
\text { Tomatoes }\end{array}$ & $\begin{array}{l}\text { Tritium, }{ }^{238} \mathrm{Pu},{ }^{239,240} \mathrm{Pu} \\
{ }^{238} \mathrm{Pu},{ }^{239.240} \mathrm{Pu} \\
\text { Tritium }\end{array}$ \\
\hline Germantown, $\mathrm{OH}$ & $\begin{array}{l}\text { Grass } \\
\text { Root crops } \\
\text { Tomatoes }\end{array}$ & $\begin{array}{l}\text { Tritium, }{ }^{238} \mathrm{Pu},{ }^{239.240} \mathrm{Pu} \\
{ }^{238} \mathrm{Pu},{ }^{239.240} \mathrm{Pu} \\
\text { Tritium }\end{array}$ \\
\hline Brookville, INa & $\begin{array}{l}\text { Grass } \\
\text { Root crops } \\
\text { Tomatoes }\end{array}$ & $\begin{array}{l}\text { Tritium, }{ }^{238} \mathrm{Pu},{ }^{239,240} \mathrm{Pu} \\
{ }_{238} \mathrm{Pu},{ }^{239,240 \mathrm{Pu}} \\
\text { Tritium }\end{array}$ \\
\hline
\end{tabular}

- Background sampling location. 
The applicable collection and analysis procedures for the media and radionuclides of Table 4-2 are documented in Mound Technical Manual MD-80030, Environmental Analytical Procedures. The specific operations which are incorporated by reference into this EMP are Operation 9281 , Plutonium in Fish and Vegetation by an Acid Leach Method and Operation 2722, Tritium in Vegetation.

\subsection{Groundwater}

Groundwater surveillance is the subject of a separate plan, the Groundwater Protection Management Program Plan (DOE, 1993b), or "GWPMPP", as required by DOE Order 5400.1. A brief summary of the GWPMPP is presented in the following sections. For more detailed information on groundwater monitoring program elements, the reader is directed to the GWPMPP which is incorporated by reference in this EMP.

\subsubsection{Introduction}

The Groundwater Protection Management Program Plan (GWPMPP) has been designed to meet all nonenvironmental restoration program requirements of the Mound Plant. Groundwater monitoring requirements covered by the GWPMPP include those associated with the:

- Safe Drinking Water Act (SDWA) for the protection of the drinking water system, the

- Resource Conservation and Recovery Act (RCRA) for compliance and surveillance monitoring, and the

- sampling program operated by Mound based on Best Management Practices (BMPs).

The GWPMPP does not include Comprehensive Environmental Response, Compensation, and Liability Act (CERCLA) investigation monitoring or other groundwater investigation requirements of the environmental restoration (ER) program. The nature and extent of CERCLA requirements for groundwater will be dependent upon the characterization component of the remedial investigation/ feasibility study (RI/FS).

\subsubsection{History}

Groundwater history relating to the Mound Plant has been well documented. The GWPMPP summarizes this history in two sections of Chapter 2. The first section delineates the environmental hazards associated with the CERCLA operable units and the RCRA-permitted sites. The other section defines the site hydrogeology including geology, water quality, and water use. 
To implement an effective groundwater surveillance program, the type and source of contaminants that pose a threat to the groundwater must be known. These areas have been identified and documented through the CERCLA process. The Phase I: Installation Assessment Mound (DOE, 1986), RCRA Facility Assessment (EPA, 1988), Mound Plant Underground Storage Tank Program Plan (EG\&G Mound, 1993a), and the Regulatory Status Review, Site Scoping Report: Volume 7- Waste Management (DOE 1993c) are examples of reports which document hazardous waste sites with the potential to release contaminants to the groundwater. Geohydrologic investigations at the Mound Plant have determined that the primary contaminants of concern in the groundwater are volatile organic compounds (VOCs) and tritium.

Another component of an effective groundwater surveillance program is a thorough understanding of the site's geology and hydrogeology. This aspect has been addressed as part of the on-going RI/FS process. An extensive discussion of the facility hydrogeology is contained in the Operable Unit 9 RI/FS Work Plan (DOE, 1992a), and in reports on the individual operable units.

\subsubsection{Groundwater Sources}

From the investigations described above, two sources of groundwater have been identified. One source is the bedrock. Groundwater movement within the bedrock is limited to joint and fracture flow, thus forming a perched water system. In areas where the bedrock intersects the ground surface, seeps have formed. This bedrock groundwater system provides no potable water for Mound and its capacity and flow are limited. However, this system can serve as mechanism for transporting contamination from the main hills of the plant site to the adjacent river valley.

The second source of groundwater is the Buried Valley Aquifer (BVA). The groundwater flow in the BVA generally follows the bedrock topography. The BVA is the major source of potable water for the Mound Plant and the neighboring communities. Consequently, the BVA was designated a sole source aquifer by the U.S. EPA in May of 1988. Protection of this aquifer is a specific concern for Mound since the BVA extends onto the western and southwestern portions of the site. Contamination released onsite at the fringes of the BVA has the highest potential to migrate into major regions of the BVA.

\subsubsection{Groundwater Monitoring Network}

The groundwater monitoring plan for Mound is presented in Chapter 3 of the GWPMPP. All existing and proposed regulatory groundwater protection monitoring requirements are listed in Tables III.1 through III.10 of the GWPMPP. The monitoring plan outlines the requirements for the SDWA, RCRAA compliance and surveillance monitoring, and Mound's BMP activities. 


\section{SDWA}

The SDWA requirements for public water systems are enforced by the Ohio EPA through the Ohio Administrative Code (OAC) Chapters 3745-81 and 3745-82. SDWA regulations require regular monitoring of drinking water sources and points of distribution for bacteriological, inorganic, organic, and radiological constituents known to be detrimental to human health. These requirements are listed in Tables III. 1 through III. 6 of the GWPMPP for a non-transient non-community public water system.

The sampling points for SDWA are the three plant production wells, the entry points to the distribution system after chlorination, and specific plant taps.

\section{RCRA Surveillance and Compliance Monitoring}

Present at Mound are active and inactive RCRA storage and treatment facilities. Mound has applied for a RCRA Part B permit for these facilities. Until the permit is issued, the Plant remains under "interim status". The Part B application, as filed, does not provide for groundwater monitoring due to the presence of engineered containment structures and leak detection systems. However, RCRA interim status regulations (40 CFR 265) require surveillance monitoring upgradient and downgradient of the site. RCRA surveillance monitoring is conducted using Wells 0118 (background location), 0123, 0129, 0156, and 0160. The locations of the monitoring wells are shown on Figure 4-4.

RCRA compliance monitoring is required of the site as an "applicable or relevant and appropriate" (ARAR) regulation for the CERCLA process (40 CFR 264). The ER Section will implement a compliance monitoring program based on the results of the RI/FS. Pending institution of this program, the Environmental Technology \& Monitoring Section has implemented a provisional monitoring program. The points of compliance for this monitoring function will be directly downgradient of the facility at the plant boundary. RCRA compliance monitoring program is conducted using Wells 0118 (background location), 0305, 0306, 0307, 0313, and 0315. The locations of these wells are also shown on Figure 4-4.

\section{BMPs}

The primary focus of groundwater-related monitoring activities conducted as best management practices (BMPs) is the evaluation of the offsite migration of radionuclides. The radionuclides of interest are tritium, plutonium-238, plutonium-239,240, uranium-233,234, and uranium-238. Table III.11 of the GWPMPP describes the extent and frequency of BMP sampling and analysis.

The sampling locations for BMP monitoring include offsite production and private wells, twelve community water supplies, selected offsite monitoring wells, and the three Mound production wells. A listing of the wells and community water supplies sampled by Mound appears in Table 4-3; well locations are shown in Figures 4-4 and 4-5. 


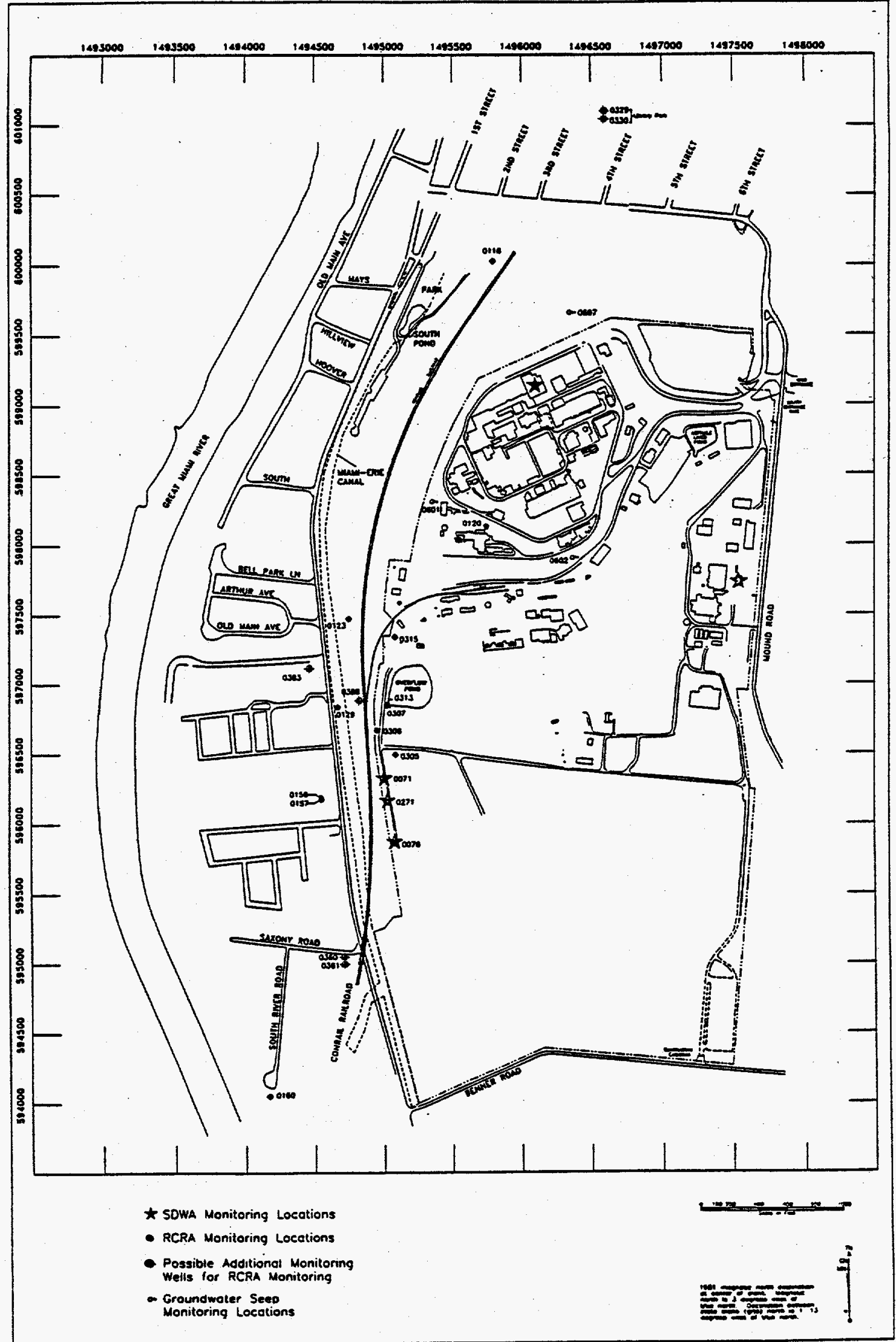

Figure 4-4. Groundwater monitoring and surveillance sampling locations 


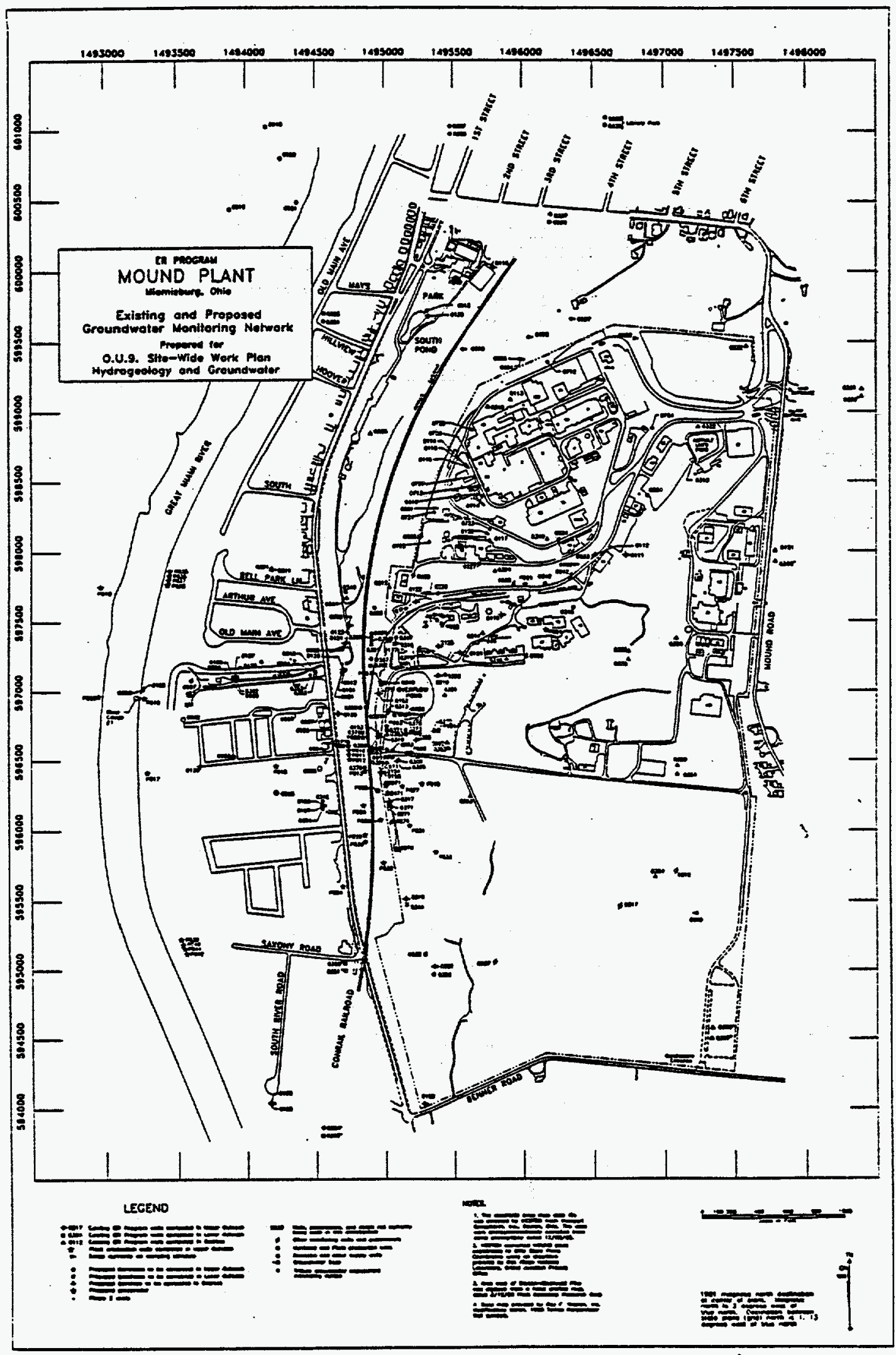

Figure 4-5. Additional groundwater sampling locations 
Table 4-3. BMP sampling of wells and water supplies for radiological constituents

\begin{tabular}{|c|c|c|c|c|c|}
\hline Offsite production and private wells & $\stackrel{q}{I}$ & 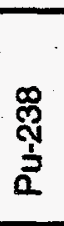 & 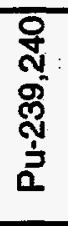 & 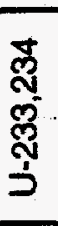 & 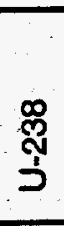 \\
\hline 0904 & $\bullet$ & $\bullet$ & $\bullet$ & $\bullet$ & $\bullet$ \\
\hline 0905 & $\cdot$ & & & & \\
\hline 0906 & - & & & & \\
\hline 0907 & $\bullet$ & & & & \\
\hline 0909 & - & & & & \\
\hline 0912 & - & & & & \\
\hline 0913 & $\cdot$ & & & & \\
\hline \multicolumn{6}{|l|}{ Community water supplies } \\
\hline Bellbrook & $\cdot$ & & & & \\
\hline Centerville & $\cdot$ & & & & \\
\hline Dayton & $\cdot$ & & & & \\
\hline Franklin & $\cdot$ & & & & \\
\hline Germantown & $\bullet$ & & & & \\
\hline Kettering & - & & & & \\
\hline Miamisburg & $\cdot$ & $\cdot$ & $\bullet$ & $\bullet$ & $\bullet$ \\
\hline Middletown & $\cdot$ & & & & \\
\hline Moraine & $\cdot$ & & & & \\
\hline Springboro & - & & & & \\
\hline Waynesville & $\cdot$ & & & & \\
\hline W. Carrollton & $\bullet$ & & & & \\
\hline
\end{tabular}


Table 4-3. Continued.

\begin{tabular}{|c|c|c|c|c|c|}
\hline Offsite monitoring wells & $\underline{\underline{p}}$ & 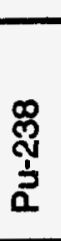 & $\begin{array}{l}\text { 웜 } \\
\text { ò } \\
\text { শ্ } \\
\grave{3} \\
0\end{array}$ & 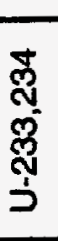 & 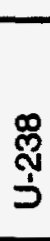 \\
\hline 0101 & $\cdot$ & & & & \\
\hline 0005 & $\cdot$ & & & & \\
\hline 0106 & $\cdot$ & & & & \\
\hline \multicolumn{6}{|l|}{ Onsite production wells } \\
\hline 0071 & - & $\bullet$ & $\cdot$ & - & $\bullet$ \\
\hline 0271 & - & $\cdot$ & - & - & $\bullet$ \\
\hline 0076 & $\bullet$ & $\cdot$ & - & $\cdot$ & $\bullet$ \\
\hline
\end{tabular}




\subsubsection{Methods and Procedures}

All methods and procedures relating to groundwater monitoring activities follow the guidelines set forth in the GWPMPP. All analyses conducted to meet the requirements of the SDWA must be performed by an Ohio EPA-certified laboratory. Such analyses must be in strict compliance with the methodologies specified in OAC 3745-81-27. Sampling procedures for RCRA surveillance and compliance must follow those established by the Quality Assurance Project Plan Standard Operating Procedures for Operable Unit 9 (OU 9 QAPP SOP). Analytical procedures for RCRA surveillance and compliance must follow U.S. EPA Contract Laboratory Program protocols. All BMP monitoring activities must follow approved procedures listed in Mound Technical Manual MD-80030, Environmental Analytical Procedures. The OU 9 QAPP (DOE, 1992b) and Mound Manual MD-80030 are incorporated by reference into this EMP.

\subsection{Multi-Media Quality Assurance Programs}

- In addition to the program-specific quality assurance (QA) activities described in previous sections of this Plan, Mound participates in broad-range QA exercises sponsored by the DOE. Such exercises provide objective evaluations of the validity of the environmental data generated by Mound. In addition to these external QA programs, Mound performs internal QA studies that make use of field and reagent blanks, internal standards, and duplicate samples.

\subsubsection{EML QA Program}

Twice each year, DOE's Environmental Monitoring Laboratory (EML) conducts blind environmental sampling exercises for DOE sites. Each participating lab is given air filter, vegetation, water, and soil samples to analyze for radiological constituents. A laboratory's performance is then evaluated by comparing their results to EML reference values. Mound documents the Plant's performance for each calendar year in the annual site environmental report.

\subsubsection{Internal QA Program}

Mound performs a number of internal QA operations. Blank samples are analyzed to verify the absence of excessive instrument contamination or background. The standard deviation of the blank is then used to calculate the lower limit of detection. Mound also routinely uses duplicate sample analysis and internal standard techniques to evaluate analytical precision. Deviations from expected values result in comprehensive reviews of the appropriate protocols. 


\subsubsection{Sample Tracking Procedures and Data Management}

It is also a primary objective of the environmental monitoring programs at Mound to ensure that adequate procedures are in place to track samples and to archive data. Mound provides for sample tracking via a series of chain-of-custody procedures. The relevant operation from MD-80030 is Operation 9284, Chain of Custody, which is incorporated by reference into this EMP.

Data management activities are governed by MD-80030 and MD-80033, Environmental Assessment Procedures. MD- 80033 documents the various data formats, logs sheets and calculational routines used to generate environmental concentration data. MD-80033 is incorporated by reference into this EMP. 


\subsection{DOSE CALCULATIONS}

Mound personnel estimate "maximum" offsite dose equivalents for each calendar year of operation. Estimates of offsite population doses are also generated. The methodologies used by Mound to meet applicable dose reporting requirements are described below.

\subsection{Exposure Routes}

Members of the public may receive radiation doses from a number of exposure pathways. For radionuclides discharged to the atmosphere, a person may inhale, or be immersed in, airborne radioactivity. Other routes of airborne exposure include ground deposition of radionuclides and consumption of food products that are contaminated by airborne releases. For radionuclides released to water, a person may consume contaminated water or fish. Other potential water-based exposure pathways involve such activities as boating and swimming. Typically, these routes of exposure are not significant contributors to dose.

The significance of a given exposure route is highly dependent on the nature of a facility's operations and the types of radionuclides handled there. The important exposure pathways for Mound are shown in Figure 5-1. Figure 5-1 also identifies the radionuclides associated with each exposure route.

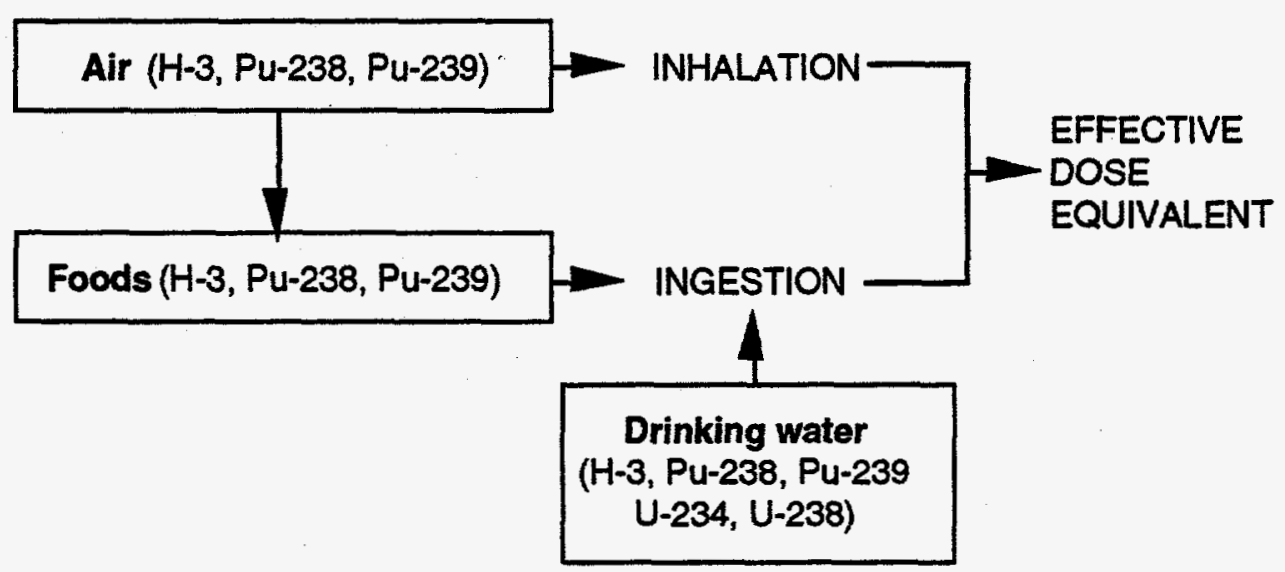

Figure 5-1. Exposure pathways for dose calculations 


\subsection{Dose Estimates Based on Measured Concentrations}

For DOE reporting requirements, doses are presented as 50-year committed effective dose equivalents (CEDEs). The CEDE is the total dose equivalent that will be received by an individual over a 50-year time period as a result of one year of exposure to ionizing radiation. The total CEDE reported is the sum of the CEDEs from the air, water and food products pathways.

CEDEs are calculated based on measured concentration data for tritium, plutonium-238, and plutonium239,240 . A CEDE for a given radionuclide is calculated as shown below. The sampling locations used to determine maximum annual average concentrations in the various environmental media are identified in Table 5-1. Table 5-1 also specifies other parameter values used in Equation 5-1.

$$
\mathrm{CEDE}=\Sigma \mathrm{C}_{\mathrm{r}} \cdot \mathrm{I}_{\mathrm{a}} \cdot \mathrm{DCF} \cdot \mathrm{CF} \quad \text { (Eq. 5-1) }
$$

where $\mathrm{CEDE}=$ total committed effective dose equivalent, mrem

$$
\begin{aligned}
\sum_{1}^{p} & =\text { summation over the exposure pathways } 1 \text { through } \mathrm{p} \\
\mathrm{C}_{\mathrm{r}} & =\text { maximum average concentration of the radionuclide } \\
\mathrm{I}_{\mathrm{a}} & =\text { annual intake of the environmental medium } \\
\mathrm{DCF} & =\text { dose conversion factor for the radionuclide and intake type } \\
\mathrm{CF} & =\text { conversion factor to accommodate dose conversion factor units }
\end{aligned}
$$


Table 5-1. Factors used to calculate CEDEs

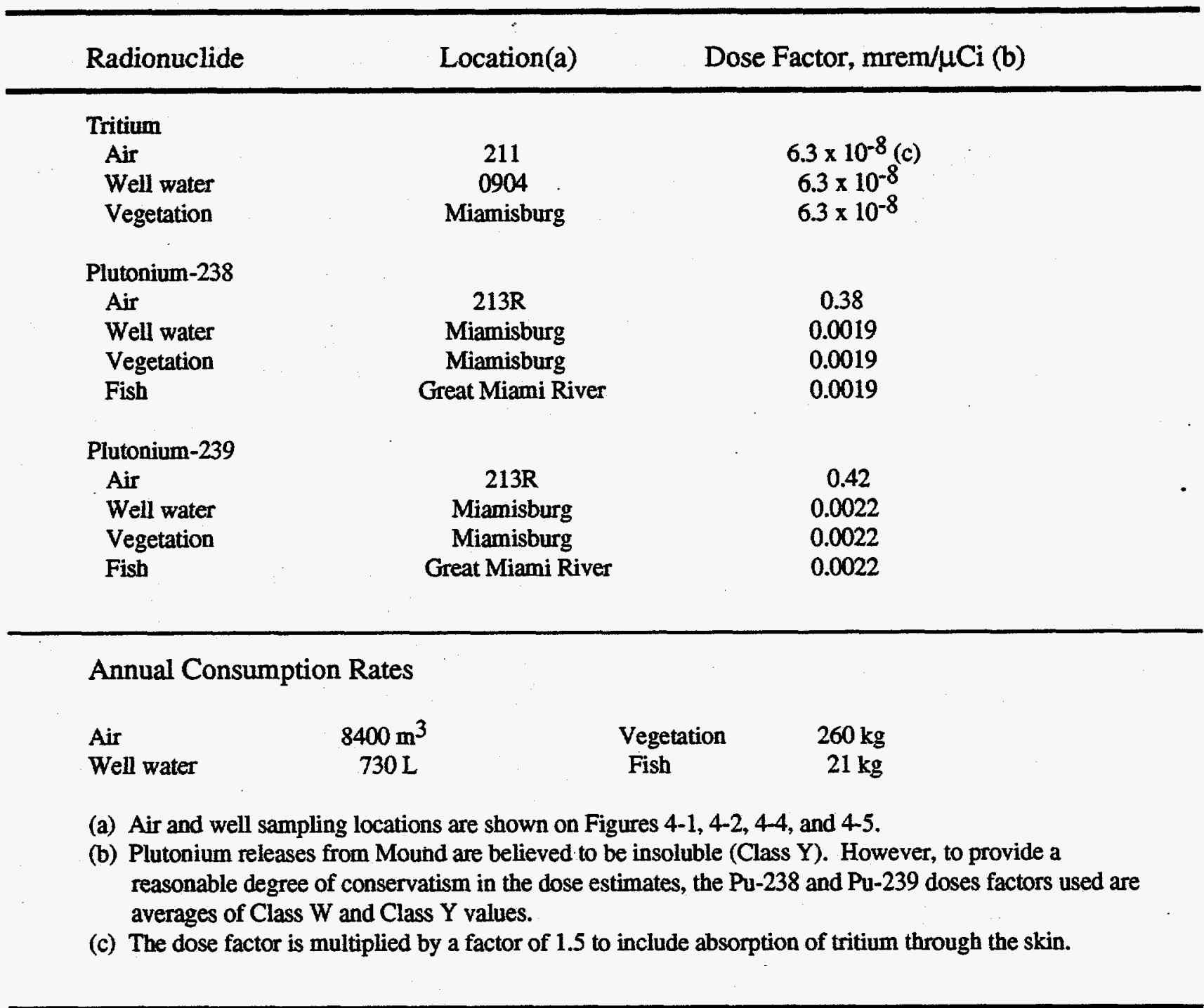

To provide an extra degree of conservatism, dose estimates are calculated based on maximum exposure conditions. The "maximum offsite individual dose", as defined for purposes of calculating a CEDE, is a hypothetical person who remains at the site boundary 24 hours per day throughout the year. This individual is assumed to have:

- continually breathed air containing the highest average radionuclide concentrations found at an onsite sampling station,

- drawn all of his drinking water from the offsite well with the highest average radionuclide concentrations, and

- used offsite foods exhibiting the highest average concentrations of radionuclides as components of his diet. 


\subsection{Dose Estimates for NESHAPs Compliance}

The National Emission Standards for Hazardous Air Pollutants; Radionuclides regulations (40 CFR 61, Subpart $\mathrm{H}$ ) limit offsite doses from DOE facilities to 10 mrem effective dose equivalent (EDE) per year. As specified in 40 CFR 61 , Subpart $\mathrm{H}$, the preferred technique for demonstrating compliance with the dose standard is a modeled approach.

Mound uses the EPA's computer code CAP-88 to evaluate doses for NESHAPs compliance. The stackspecific parameters used as input to the code are shown in Table 5-2. Other key input data include annual radionuclide release rates and meteorological data for the year of interest. Whenever possible; Mound uses site-specific data as input to the code.

The output from the CAP-88 run provides an estimate of the maximum offsite EDE via atmospheric exposure routes. This dose is then compared with the 10-mrem standard for purposes of evaluating compliance with 40 CFR 61 , Subpart H. CAP-88 also produces estimates of offsite population doses via atmospheric exposure routes. These doses are also reported to the EPA on an annual basis.

Table 5-2. CAP-88 input data

\begin{tabular}{|c|c|c|c|c|c|}
\hline & $\begin{array}{c}\text { Stack } \\
\text { IDs }\end{array}$ & $\begin{array}{l}\text { Actual or } \\
\text { Composite } \\
\text { Stack } \\
\text { Height } \\
\text { (meters) }\end{array}$ & $\begin{array}{l}\text { Actual or } \\
\text { Composite } \\
\text { Stack } \\
\text { Diameter } \\
\text { (meters) }\end{array}$ & $\begin{array}{l}\text { Actual or } \\
\text { Composite } \\
\text { Exit } \\
\text { Velocity } \\
\text { (meters/sec) }\end{array}$ & Radionuclide(s) \\
\hline Stack 1 & $\mathrm{HH}$ & 48 & 1.7 & 1.2 & $\mathrm{H}-3$ \\
\hline $\begin{array}{l}\text { Composite } \\
\text { Stack } 2\end{array}$ & $\begin{array}{l}\text { NCPDF/ } \\
\text { SW Cave }\end{array}$ & 42 & 0.8 & 15.2 & $\begin{array}{l}\text { H-3 } \\
\text { Pu-238 } \\
\text { Pu-239 } \\
\text { U-234 } \\
\text { U-238 }\end{array}$ \\
\hline Stack 3 & BD 58 & 45 & 2.0 & 12.0 & $\begin{array}{l}\mathrm{H}-3 \\
\text { Pu-238 } \\
\text { Pu-239 }\end{array}$ \\
\hline $\begin{array}{l}\text { Composite } \\
\text { Stack } 4\end{array}$ & $\begin{array}{l}\text { SM/ } \\
\text { T WEST/ } \\
\text { T EAST }\end{array}$ & 60 & 2.0 & 10.4 & $\begin{array}{l}\mathrm{H}-3 \\
\mathrm{Pu}-238 \\
\text { Pu-239 } \\
\mathrm{U}-234 \\
\mathrm{U}-238\end{array}$ \\
\hline $\begin{array}{l}\text { Composite } \\
\text { Stack } 5\end{array}$ & $\begin{array}{l}\text { WDLR/ } \\
\text { WDHR/ } \\
\text { WDSS }\end{array}$ & 16 & 0.6 & 6.8 & $\begin{array}{l}\mathrm{H}-3 \\
\mathrm{Pu}-238 \\
\mathrm{Pu}-239\end{array}$ \\
\hline
\end{tabular}




\subsection{PREPARATION AND DISPOSITION OF REPORTS}

This chapter provides an overview of the reporting requirements applicable to the environmental monitoring programs at Mound. Such requirements have been established by federal and local statutes and regulations, and by Department of Energy orders. Table 6-1, which begins on the following page, summarizes these requirements. In the table, reports, due dates, and regulatory drivers are identified.

Timely submission of the majority of these reports is the responsibility of the Environmental Technology \& Monitoring Section of EG\&G Mound Applied Technologies. Reporting responsibilities for unplanned "environmental occurrences" and/or releases in excess of "reportable quantities" are specified in the Mound Plant DOE Order 5000.3B Occurrence Reporting and Processing of Information Plan. The $5000.3 B$ response plan (EG\&G, 1993b) is incorporated by reference into this EMP. 
Table 6-1. Applicable reporting requirements

\begin{tabular}{|c|c|c|c|}
\hline Report & $\begin{array}{l}\text { Due } \\
\text { Date }\end{array}$ & Driver & Description \\
\hline $\begin{array}{l}\text { Annual Site } \\
\text { Environmental Report }\end{array}$ & June 1 & DOE Order 5400.1 & $\begin{array}{l}\text { The annual site environmental report summarizes } \\
\text { radiological and nonradiological environmental } \\
\text { monitoring results for the previous calendar year. } \\
\text { The report describes the status of the facility with } \\
\text { respect to major environmental statutes and } \\
\text { permit conditions. Effluent data for the previous } \\
\text { year, and estimates of potential offsite impacts, } \\
\text { are also included. The report is submitted to DOE } \\
\text { for distribution to the public. }\end{array}$ \\
\hline $\begin{array}{l}\text { Annual NESHAPs } \\
\text { Compliance Report }\end{array}$ & June 30 & 40 CFR 61 , Subpart H & $\begin{array}{l}\text { This report documents the site's compliance with } \\
\text { the dose standard of } 40 \text { CFR } 61 \text {, Subpart H. The } \\
\text { report is submitted to the U.S. EPA through the } \\
\text { U.S. DOE. }\end{array}$ \\
\hline $\begin{array}{l}\text { SARA Title III } \\
\text { Section } 311,312 \text { Report }\end{array}$ & March 1 & $\begin{array}{l}\text { SARA Title III, } \\
\text { Emergency Planning } \\
\text { and Community } \\
\text { Right-to-Know Act }\end{array}$ & $\begin{array}{l}\text { Facilities at which "hazardous" and "extremely } \\
\text { hazardous" chemicals are stored or used in } \\
\text { excess of specific thresholds must submit annual } \\
\text { inventory information to the local emergency } \\
\text { planning commissions, state emergency response } \\
\text { agencies, and local fire departments. The report } \\
\text { is submitted to these agencies through the } \\
\text { appropriate area office of DOE. }\end{array}$ \\
\hline $\begin{array}{l}\text { SARA Title III } \\
\text { Section } 313 \text { Report }\end{array}$ & July 1 & $\begin{array}{l}\text { SARA Title III, } \\
\text { Emergency Planning } \\
\text { and Community } \\
\text { Right-to-Know Act }\end{array}$ & $\begin{array}{l}\text { Facilities releasing hazardous materials in excess } \\
\text { of specific thresholds must file a Toxic Chemical } \\
\text { Release inventory form, Form R, each year with } \\
\text { the state and/or federal EPA. }\end{array}$ \\
\hline
\end{tabular}




\begin{tabular}{|l|l|l|l|}
\hline Report & $\begin{array}{l}\text { Due } \\
\text { Date }\end{array}$ & Driver & Description \\
\hline $\begin{array}{l}\text { Discharge Monitoring } \\
\text { Report }\end{array}$ & Monthly & $\begin{array}{l}\text { Clean Water Act, } \\
\text { NPDES permit }\end{array}$ & $\begin{array}{l}\text { Facilities governed by a National Pollutant } \\
\text { Discharge Elimination System permit must submit } \\
\text { discharge data each month to the state and/or } \\
\text { federal EPA. The report documents the site's } \\
\text { compliance status for each regulated outfall. }\end{array}$ \\
\hline Occurrence Reports & As needed & DOE Order 5000.3B & $\begin{array}{l}\text { Pursuant to DOE Order 5000.3B, specific } \\
\text { offnormal events must be reported to DOE. The } \\
\text { reportable events are categorized by the nature } \\
\text { and the severity of the incident. }\end{array}$ \\
\hline Radionuclide Release Report & As needed & DOE Order 5400.4 & $\begin{array}{l}\text { Releases of radionuclides in excess of "reportable } \\
\text { quantities" must be reported to the EPA National } \\
\text { Response Center and to DOE. }\end{array}$ \\
\hline $\begin{array}{l}\text { Radioactive Effluent and Onsite } \\
\text { Discharge Data Reports }\end{array}$ & April 1 & DOE Order 5400.1 & $\begin{array}{l}\text { All offsite and onsite releases of radioactive } \\
\text { materials in airborne and liquid effluents must be } \\
\text { reported to the Information Systems Branch of } \\
\text { EG\&G Idaho for each calendar year. }\end{array}$ \\
\hline $\begin{array}{l}\text { Department Pollution Abatement } \\
\text { Projects }\end{array}$ & $\begin{array}{l}\text { May 1 and } \\
\text { December } \\
15\end{array}$ & OMB Circular A-106 & $\begin{array}{l}\text { DOE pollution abatement projects are reported to } \\
\text { DOE/Headquarters. The reporting format is } \\
\text { established by EPA and DOE guidance. }\end{array}$ \\
\hline
\end{tabular}




\subsection{REFERENCES}

40 CFR 58. Ambient Air Quality Surveillance.

40 CFR 61, Subpart H. National Emission Standards for Emissions of Radionuclides Other Than Radon From Department of Energy Facilities.

40 CFR 136. Guidelines Establishing Test Procedures for the Analysis of Pollutants.

40 CFR 264. Standards for Owners and Operators of Hazardous Waste Treatment, Storage, and Disposal Facilities.

40 CFR 265. Interim Status Standards for Owners and Operators of Hazardous Waste Treatment, Storage, and Disposal Facilities

DOE, 1986. U.S. Department of Energy, Phase I: Installation Assessment Mound, Assessment and Response Program, Albuquerque, NM.

DOE, 1989. U.S. Department of Energy Order 5400.4, Comprehensive Environmental Response, Compensation, and Liability Act Requirements.

DOE, 1990. U.S. Department of Energy Order 5400.1, General Environmental Protection Program.

DOE, 1991a. U.S. Department of Energy, Environmental Regulatory Guide for Radiological Effluent Monitoring and Environmental Surveillance, Report Number DOE/EH-0173T, Assistant Secretary for Environment, Safety and Health, Washington, D.C.

DOE, 1991b. U.S. Department of Energy Order 5700.6C, Quality Assurance.

DOE, 1992a. U.S. Department of Energy, Operable Unit 9 RI/FS Work Plan, Mound Plant, Miamisburg, Ohio, Albuquerque, NM.

DOE, 1992b. U.S. Department of Energy, Remedial Investigation, Operable Unit 9, Site-Wide Quality Assurance Project Plan, Albuquerque, NM.

DOE, 1993a. U.S. Department of Energy Order 5400.5, Radiation Protection of the Public and the Environment.

DOE, 1993b. U.S. Department of Energy, Groundwater Protection Management Program Plan, Mound Plant, Miamisburg, $\mathrm{OH}$.

DOE, 1993c. U.S. Department of Energy, Site Scoping Report: Volume 7-Waste Management, Mound Plant, Miamisburg, Ohio, Albuquerque, NM. 
DOE, 1993d. U.S. Department of Energy Order 5000.3B, Occurrence Reporting and Processing of Operations Information.

EG\&G Mound, 1993a. EG\&G Mound Applied Technologies, Draft Report, Active Underground Storage Tank Program Plan, Miamisburg, $\mathrm{OH}$.

EG\&G Mound, 1993b. EG\&G Mound Applied Technologies, Occurrence Reporting and Processing of Operations Information Plan, Miamisburg, $\mathrm{OH}$.

EPA, 1987. U.S. Environmental Protection Agency, On-Site Meteorological Program Guidance for Regulatory Modeling Applications, Office of Air Quality Planning and Standards, Research Triangle Park, NC.

EPA, 1988. U.S. Environmental Protection Agency, RCRA Facility Assessment (RFA), U.S. DOE Mound Facility in Miamisburg, Ohio, Region 5, Chicago, IL.

EPA, 1992. U.S. Environmental Protection Agency, User's Guide for CAP88-PC, Version 1.0, Report Number 402-B-92-001, Office of Radiation Programs, Las Vegas, NV.

MD-10176. Environmental Section - Quality Control Manual, Issue 5, EG\&G Mound Applied Technologies, Miamisburg, $\mathrm{OH}$.

MD-10321. Quality Plan for Bioassay and Environmental Monitoring, Issue 1, EG\&G Mound Applied Technologies, Miamisburg, $\mathrm{OH}$.

MD-80030. Environmental Analytical Procedures, Issue 22, EG\&G Mound Applied Technologies, Miamisburg, $\mathrm{OH}$.

MD-80033. Environmental Analytical Procedures, Issue 2, EG\&G Mound Applied Technologies, Miamisburg, $\mathrm{OH}$.

Moore etal., 1979. Moore, R.E., Baes, C.F., III, McDowell-Boyer, L.M., Watson, A.P., Hoffman, F.O., Pleasant, J.C., and Miller, C.W., AIRDOS-EPA: A Computerized Methodology for Estimating Environmental Concentrations and Dose to Man from Airborne Releases of Radionuclides, Report Number EPA 520/1-79-009, U.S. Environmental Protection Agency, Office of Radiation Programs, Washington, D.C.

OMB, 1974. Office of Management and Budget, Reporting Requirements in Connection with the Prevention, Control, and Abatement of Environmental Pollution of Existing Federal Facilities, Washington, D.C.

Sagendorf et al., 1982. Sagendorf, J.F., Goll, J.T., and Sandusky, W.F.,XOQDOQ: Computer Program for the Meteorological Evaluation of Routine Effluent Releases at Nuclear Power Stations, Report Number NUREG/CR-2919, Battelle Pacific Northwest Laboratories, Richland, WA. 
Waite, 1973a. D. A. Waite, An Analytical Technique for Distributing Air Sampling Locations Around Nuclear Facilities, Report Number BNWL-SA-4534, Battelle Pacific Northwest Laboratories, Richland, WA.

Waite, 1973b. D. A. Waite, Analysis of an Analytical Technique for Distributing Air Sampling Locations Around Nuclear Facilities, Report Number BNWL-SA-4676, Battelle Pacific Northwest Laboratories, Richland, WA. 
